\title{
Simple and Cost-Effective Biomonitoring Method for Assessing Pollution in Tropical African Rivers
}

\author{
Julius D. Elias \\ Tanzania Industrial Research and Development Organization (TIRDO), Dar es Salaam, Tanzania \\ Email: julius.zeanimo@gmail.com,animoj@yahoo.com
}

How to cite this paper: Elias, J.D. (2021) Simple and Cost-Effective Biomonitoring Method for Assessing Pollution in Tropical African Rivers. Open Journal of Ecology, 11, 407-436.

https://doi.org/10.4236/oje.2021.114027

Received: November 20, 2020

Accepted: April 24, 2021

Published: April 27, 2021

Copyright $\odot 2021$ by author(s) and Scientific Research Publishing Inc. This work is licensed under the Creative Commons Attribution International License (CC BY 4.0).

http://creativecommons.org/licenses/by/4.0/

\begin{abstract}
Adoption rule whereby tropical African regions rely on non-tropical biomonitoring methods to assess water pollution in their rivers has been hindered by geographical incompatibility due to environmental variations between the regions that affect the capability and reliability of adopted method. Likewise, inclusion of all identified macroinvertebrate assemblages in developing the existing biomonitoring methods (i.e., South African Scoring System (SASS5) and Tanzania Riverine Scoring System (TARISS)) has made them complex taxonomically as their use requires users of greater expertise and much time during taxa identification. Such taxonomic complications and conflicting aspects regarding the adoption or modification of non-tropical biomonitoring methods in developing tropical biomonitoring methods have therefore necessitated the design of this study in order to develop simple and cost-effective tropical African biomonitoring methods, for initial application in Tanzanian rivers. Six pairwise screening criteria were employed to select orders with distinctive potential for inclusion in developing simple and cost-effective biomonitoring method. Only Ephemeroptera, Diptera, Odonata and Trichoptera (EDOT) orders met all six inclusion criteria after showing their ability to discern reference sites from monitoring sites and correlating strongly with environmental variables. Being developed using only four diverse orders with the wider range of occurrences and sensitivity to pollution, the EDOT method will minimize data variability, the need for greater expertise, cost, and time during taxa identification. The novelty of the present approach lies on the simplification of the taxonomic complication that is inherent in existing indices for four decades and modelling application to simulate sensitivity weightings for taxa with unknown sensitivity score ratings.
\end{abstract}

\section{Keywords}

Assessment, Biomonitoring Method, Pollution, Ecosystem, Macroinvertebrate 


\section{Introduction}

Despite the worldwide popularity and longevity of the biomonitoring concept, the regional share and application of the biomonitoring methods between tropi$\mathrm{cal}$ and non-tropical regions are not rational. Tropical African rivers are known to be more speciose than other regions but their taxonomical and ecological knowledge on macroinvertebrates is still incomplete [1] [2] [3]. Such knowledge gap has hindered the potential use of tropical macroinvertebrate species in developing biomonitoring method(s) that can accurately evaluate the integrity of riverine ecosystems [2]. As a result, Rapid Biomonitoring Methods (RBMs), which have been developed for the past four decades in non-tropical regions using local macroinvertebrates [4]-[13], were adopted and/or modified to develop the Namibia Scoring System (NASS) in Namibia [14], Okavango Assessment System (OKAS) in the Okavango Delta [15], the Zambia Invertebrate Scoring System (ZISS) in Zambia [16], the Tanzania Riverine Scoring System (TARISS) [17] and Ethiopian Biomonitoring Scoring System (ETHbios) [18] for use in assessing pollution in tropical African rivers. Presence of geographical differences between tropical and non-tropical regions may, however, affect the capability, functioning, compatibility and reliability of the existing non-tropical biomonitoring methods when opted and applied on tropical rivers [1] [2] [19] [20]. As such, there is a risk of having unreliable findings when non-tropical biomonitoring methods are adopted, refined and used to assess water pollution in tropical African rivers.

Ecological and taxonomical variations between the regions can as well lead to variation in macroinvertebrate taxa composition, and their sensitivity levels to disturbance and general ecosystem impairment [21]. For instance, one ephemeropteran family (Teloganodidae) and five trichopteran families (Barbarochthonidae, Glossosomatidae, Hydrosalpingidae, Petrothrincidae and Sericosostomatidae) are prevalent in the southwest cape of South Africa representing the Mediterranean regions, as opposed to ephemeropterans (Ephemerythidae and Dicercomyzidae) which are endemically widespread in both afro-tropical and tropical regions [12] [14] [17]. Moreover, macroinvertebrate taxa in Temperate, Mediterranean, Arid and Semi-Arid regions do not necessarily correspond with those in tropics to confirm the existence of general adoption rules among macroinvertebrate-based methods from other regions [1] [3] [22] [23] [24]. Such varying regional complexities have increased recognition among ecologists on the new demands for having regional specific methods to render data accuracy in biomonitoring programmes [2]. Similarly, the inclusion of all identified macroinvertebrate assemblages in the existing biomonitoring methods (i.e., ETHbios, SASS5 and TARISS) has made their use more complex taxonomically and less cost-effective [2] [12]. Such taxonomic complications and conflicting aspects regarding the adoption of non-tropical biomonitoring methods in developing tropical biomonitoring methods have therefore necessitated the design of this study. 
Novelty of the approach lies in the simplification of the taxonomic complication that has characterized the existing biomonitoring methods for more than four decades. Being developed using only four diverse orders (Appendix 1) with wider range of occurrences and sensitivity to pollution, EDOT method minimizes data variability, the need for greater expertise, cost, and time during taxa identification, and the aspects that are not hitherto considered by existing biomonitoring methods. Therefore, the simplified method will provide guidelines and directions to meet current and anticipated future status of water pollution along the tropical African rivers towards the achievement of at least a good ecological status for all surface waters.

\section{Materials and Methods}

\subsection{Description of Study Areas}

Eighty-five (85) sampling sites of varying degradation levels along Pangani and Wami-Ruvu river basins were selected for sampling to ensure the characterization of macroinvertebrate taxa and determination of physico-chemical parameters (Figure 1). Pangani river basin is found within the north and north-eastern coastal Tanzania's ecoregion, whereas the Wami-Ruvu basin occupies the central and eastern coastal Tanzania's ecoregion. However, the basins provide a wide range of riverine systems, climate, geology, topography and human disturbance within different hydro-geological patterns. The mean annual rainfall between 1100 and $3000 \mathrm{~mm}$ per annum, with a maximum mean temperature of $28^{\circ} \mathrm{C}$ to $35^{\circ} \mathrm{C}$ in the dry season, and lowest of $14^{\circ} \mathrm{C}$ to $18^{\circ} \mathrm{C}$ during the wet season.

The Pangani river basin is located in the north-eastern mainland Tanzania, $36^{\circ} 23^{\prime} \mathrm{E}$ to $39^{\circ} 13^{\prime} \mathrm{E}$ and $03^{\circ} 03^{\prime} \mathrm{S}$ to $05^{\circ} 59^{\prime} \mathrm{S}$ with an altitude ranging from 0 to $4500 \mathrm{~m}$. The basin has an estimated area of about $43,650 \mathrm{~km}^{2}$ that covers Arusha $\left(2369.76 \mathrm{~km}^{2}\right)$, Manyara $\left(17,911.35 \mathrm{~km}^{2}\right)$, Kilimanjaro $\left(10,346.76 \mathrm{~km}^{2}\right)$, and Tanga $\left(10,223.17 \mathrm{~km}^{2}\right)$ regions. Land use practices along the Pangani basin range from small-scale farming to large-scale mechanized agriculture, overexploitation of riparian vegetation, construction of dams and hydropower projects, grazing, bathing and washing, dumping of industrial and domestic wastes and human settlement.

The Wami-Ruvu river basin is elongated and extends from the central part of Tanzania towards the eastern part between $36^{\circ} 00^{\prime} \mathrm{E}$ and $39^{\circ} 00^{\prime} \mathrm{E}$ and $05^{\circ} 00^{\prime} \mathrm{S}$ to $07^{\circ} 00^{\prime} \mathrm{S}$ with an altitude of between 0 and $2500 \mathrm{~m}$ before draining into the Indian Ocean at Saadani village. It extends from Dodoma, through Morogoro, Coast, and Dar es Salaam regions, covering a total area of $72,930 \mathrm{~km}^{2}$ of wide plains and mountain ranges. Human activities that are impacting the Wami-Ruvu river basin include mining, brick making, poor agricultural practices involving application of agrochemicals, saline water intrusion, uncontrolled and illegal water obstruction for irrigation, bathing and washing along the river basin, fauna droppings, and disposal of untreated industrial and domestic wastes. 


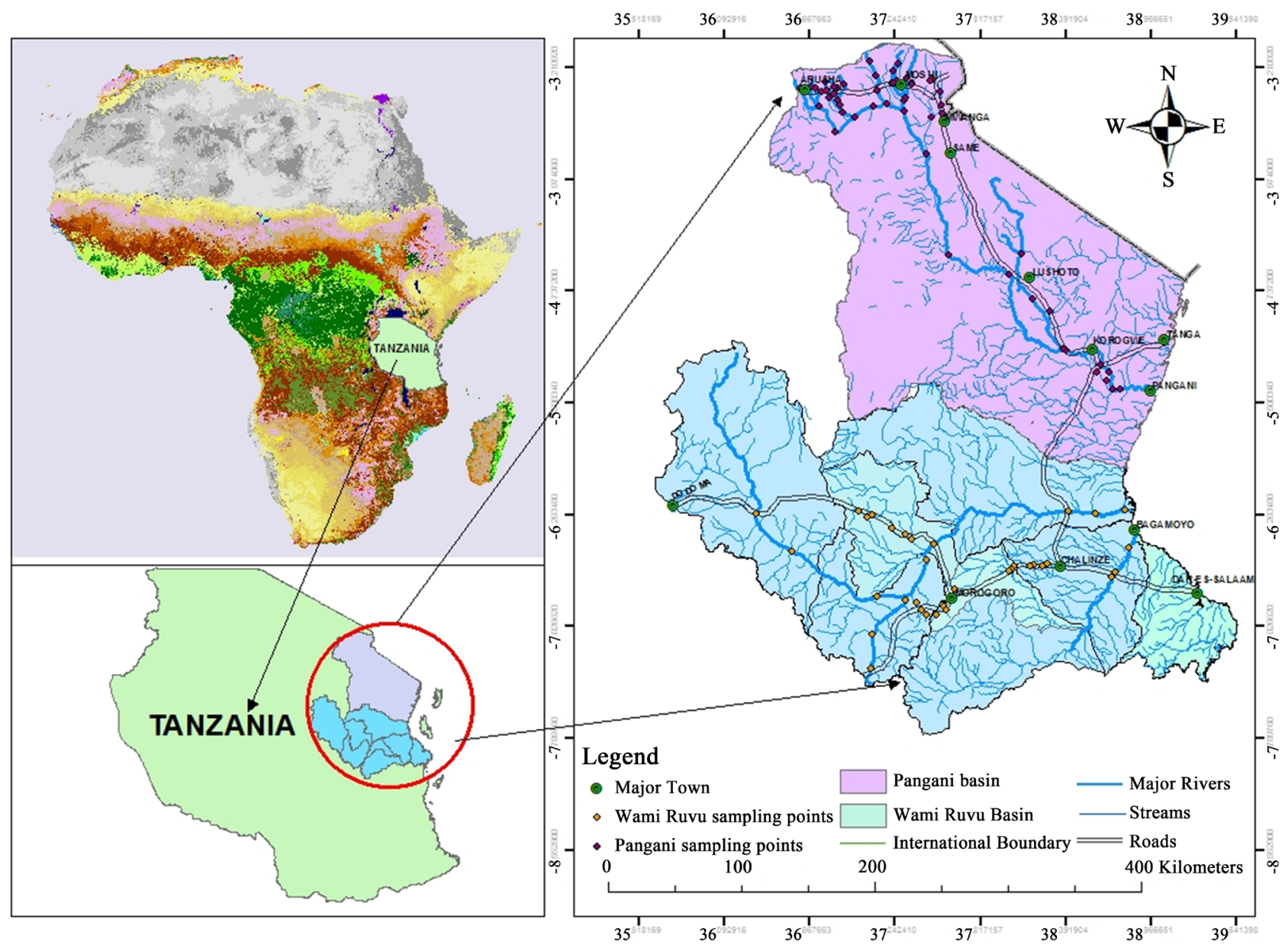

Figure 1. Tanzanian map showing sampling sites along Pangani and Wami-Ruvu basins.

\subsection{Sampling Design}

The two basins were divided into two site categories representing reference (least impacted) and monitoring (impacted) sites in accordance with Barbour et al. [8]. Water and macroinvertebrate assemblage samples were collected at each site near the end of dry, short and long-rain seasons to capture the effect of respective seasons. The sampling sites were selected on the basis of habitat score selection criteria: presence and/or absence of sustained anthropogenic disturbances, pools, riffles and runs, and degree of water physico-chemical, and habitat degradation.

\section{Selection of Reference and Monitoring Sites}

Habitat features were scored with the EPA Rapid Bioassessment Protocol (RBP) Habitat Assessment procedure prescribed by Barbour et al. [8]. This numerical scoring procedure qualitatively evaluates 200 meters reach for both spatial and longitudinal scales in order to distinguish reference sites from monitoring sites. Twenty-five habitat components described in Appendix 2 were assessed to categorize reference and monitoring sites. These include epifaunal substrate quantity and quality, embeddedness/siltation, velocity/depth regimes, sediment 
deposition, channel flow status, channel sinuosity, channel alteration, hydrological modifications, frequency of riffles or beds, in-stream flow modification, large and small scale farming, direct domestic pollution (washing, bathing, discharge and disposal), direct industrial pollution, livestock keeping, informal settlements, stream bank stability, nutrient enrichment, water quality and appearance, bank grass cover (graze), presence of exotic vegetation, canopy cover, bank vegetation protection, pool variability, pool substrate characterization, and riparian zone width. Each habitat component was scored on a 20-point scoring system to make the maximum summation of 500 points. Habitat score was calculated in each site by summing all rated screening criteria at a site (to get a total habitat score) and divided it by the highest possible score, before expressing it in percentage. The percentage habitat scores were then used to classify sites into two groups based on their degree of disturbance expressed as percentage. The first class having $\geq 90 \%$ degree of "naturalness" were considered as reference sites, whereas those with less than $90 \%$ naturalness are categorized as monitoring sites (Appendix 3).

\subsection{Physico-Chemical Data Collection and Analysis}

Water physico-chemical parameters i.e., $\mathrm{pH}$, dissolved oxygen (DO), temperature, turbidity, conductivity, total dissolved solids (TDS), ammonia $\left(\mathrm{NH}_{4}^{+}-\mathrm{N}\right)$, potassium $\left(\mathrm{K}^{+}\right)$, sulphate $\left(\mathrm{SO}_{4}^{2-}\right)$, soluble reactive phosphorus (SRP), nitrate $\left(\mathrm{NO}_{3}^{-}-\mathrm{N}\right)$ and nitrite $\left(\mathrm{NO}_{2}^{-}-\mathrm{N}\right)$ plus Biological Oxygen Demand (BOD) and Chemical Oxygen Demand (COD) were measured. Water temperature, conductivity, DO, TDS, and $\mathrm{pH}$ were measured and recorded in situ at each site using a multi-sensor probe device (Water Quality Instrument [Model 6,050,000]) while turbidity was measured using a turbidity meter. Laboratory analysis of water chemistry variables involved the filtering of collected water samples using 0.45 $\mu \mathrm{m}$ glass fibre filters and placing them in hydrochloric acid washed polythene bottles before being preserved in a cool box at $\leq 10^{\circ} \mathrm{C}$. The samples were then taken to the Department of Aquatic Sciences and Fisheries Laboratory of the University of Dar es Salaam for analysis of chemical parameters.

Nitrate $\left(\mathrm{NO}_{3}^{-}-\mathrm{N}\right)$, nitrite $\left(\mathrm{NO}_{2}^{-}-\mathrm{N}\right)$, ammonia $\left(\mathrm{NH}_{4}^{+}-\mathrm{N}\right)$ and $\mathrm{SRP}\left(\mathrm{PO}_{4}^{3-}-\mathrm{P}\right)$ were analyzed using standard spectrophotometric methods described in APHA [25]. Ammonia was determined using the phenate method, nitrate and nitrite concentrations by cadmium reduction method, SRP analyzed using molybdate ascorbic acid method, $\mathrm{SO}_{4}^{2-}$ by turbid-metric method, $\mathrm{BOD}$ by instrumental (BOD track) method and COD using instrumental (semi-automated) calorimetric method [25] [26].

\subsection{Macroinvertebrate Samples}

Macroinvertebrates were sampled according to sampling methods developed by Barbour et al. [8], Dickens and Graham [12] and Lowe et al. [16], which were refined prior to use in order to match the study objectives and reflect tropical 
aquatic environment. The refinement/modification includes the use of tighter sampling technique, analytical methods and procedures. Macroinvertebrate samples were collected near the end of long-rain, short-rain and dry seasons in order to capture the effect of the respective seasons on macroinvertebrates and the recovery of the riverine ecosystems. Samples were collected throughout the study period by the same operator using a $30 \mathrm{~cm} \times 30 \mathrm{~cm}$ kick-net with a 250- $\mu \mathrm{m}$ mesh size.

To avoid bias due to spatial and longitudinal variations and/or heterogeneity impact, samples were collected separately from different biotopes found available at each site. The biotopes include; stone (comprised stone in current-SIC and stone out of current-SOOC), vegetation (marginal and in-water vegetation) and GSM (gravel-sand-mud/silt). Each biotope was disturbed (by hand scooping, feet stirring and kicking, or net sweeping) while moving the kick-net that was placed closely downstream towards upstream for one minute to trap the detached macroinvertebrates. Apart from the available biotopes, one-minute visual observation and hand picking of macroinvertebrates were also done to increase site sample accuracy. All samples were then pooled as one composite sample and sorted grossly in the field to order level before preservation in 10\% formaldehyde solution for subsequent laboratory processing, identification and recording. In the laboratory, macroinvertebrate specimens were identified to the lowest possible taxonomic level (family level) with the help of a dissecting microscope $(10 \times 45$ magnifications for detailed observation) and Day et al. [27] [28], Thorp and Covich [29], Day and De Moor [30] [31], Day et al. [32], De Moor et al. [33] [34] and Stals and De Moor [35] identification keys, followed by listing and counting of individuals.

\subsection{Selection Criteria for Potential Orders for Use in Biomonitoring Methods}

Numerical and statistical redundant criteria were employed to select key bio-indicator families with the potential of separating reference sites from monitoring sites for use in developing a simple and cost-effective method (Figure 2). The selection was done by performing numerical truncate test, a non-parametric Mann-Whitney $U$ test $(p<0.05)$, the degree of inter-quartile (IQ) overlap in Box-and-Whisker plots, Spearman's rank $\left(r_{s}\right)$ correlation analysis, more diverse orders (with $>10$ taxa) criterion and validation test using CAP and Spearman's rank correlation $\left(r_{s}\right)$. Orders with abundances of $>0.5 \%$, a $p$-value $<0.05$ in a Mann-Whitney $U$ test, a sensitivity score of $3, r_{s}<75 \%$ and higher numbers of taxa were considered as potential orders for inclusion in developing biomonitoring methods [9] [36].

1) Truncate test

Numerically, orders were truncated in order to eliminate the rare taxa (with $<0.5 \%$ of total macroinvertebrate abundance) that would contribute only noise to other statistical analyses. To reduce variability in the data set, only dominant taxa (with total macroinvertebrate abundance of $>0.5 \%$ ) were retained for further 


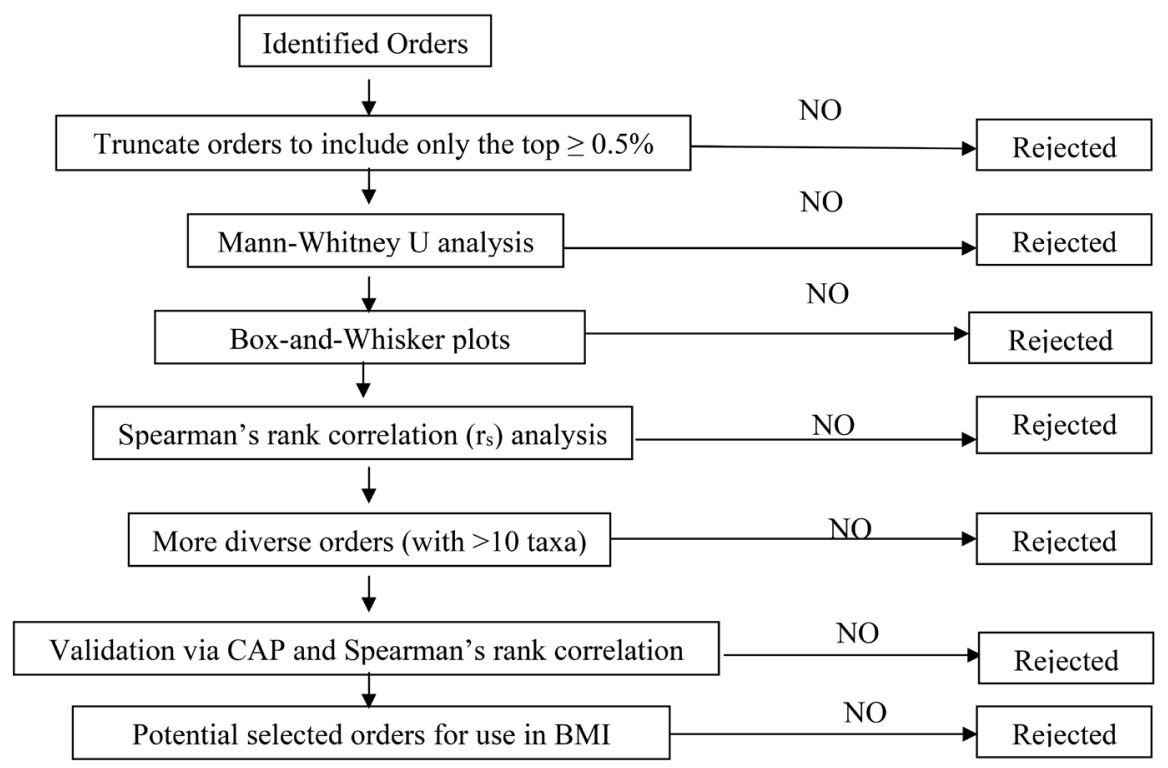

Figure 2. Selection criteria for potential BMI's orders.

statistical analysis [37].

\section{2) Mann-Whitney $U$ test with $p$ value $<0.05$}

A non-parametric Mann-Whitney $U$ test was used as a statistical testing criterion for eliminating the resulting orders that exhibited no significant differences ( $p>0.05$ ) after pairwise comparison of abundances for orders observed in reference sites with those in monitoring sites. In that regard, orders found to have a p-value of $<0.05$ in the test were considered to be strong discriminators of reference and monitoring conditions [9] [36] [38].

\section{3) Box-and-Whisker test}

Sensitivity scores of the orders were based on the levels of overlapping interquartile ranges of Box-and-Whisker plots (Figure 3) according to the modified procedures prescribed by Barbour et al. [8], Baptista et al. [9], and Ferreira et al. [38]. Box-and-Whisker plots of reference and monitoring sites were examined in order to determine if there was a significant vertical separation between their interquartile ranges of the corresponding conditions. For each order, sensitivity scores of three, two and less than two, with the thresholds of median ranges between $25^{\text {th }}$ and $75^{\text {th }}$ percentiles of the reference site were used as selection criteria for potential orders representing a pivotal assessment tool. A sensitivity score of three (which meets the reference condition) was given if there was no overlap in the interquartile range (IQ) of Box-and-Whisker plots [9] [36] [38]. A score of two (that represents an intermediate condition) was scored if there was a partial overlap of the IQ range with both medians being outside of the overlap [9] [36] [38]. Likewise, a sensitivity score of less than two was given if the orders' abundances were below the $25^{\text {th }}$ percentile. These scores were attained if: a) there was a moderate overlap of IQ range but one median appeared outside the IQ range overlap; b) one range completely overlapped the other IQ range but one median is outside the IQ range overlap; and c) both medians were inside the IQ range overlap. 
(i) Score 3 (for the values $>75 \%$ IQ)

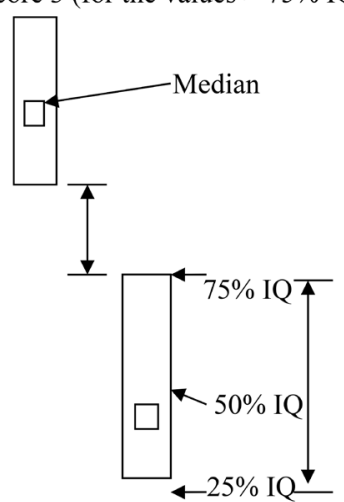

(iii) Score $<2$ (for the values below $25 \%$ IQ)

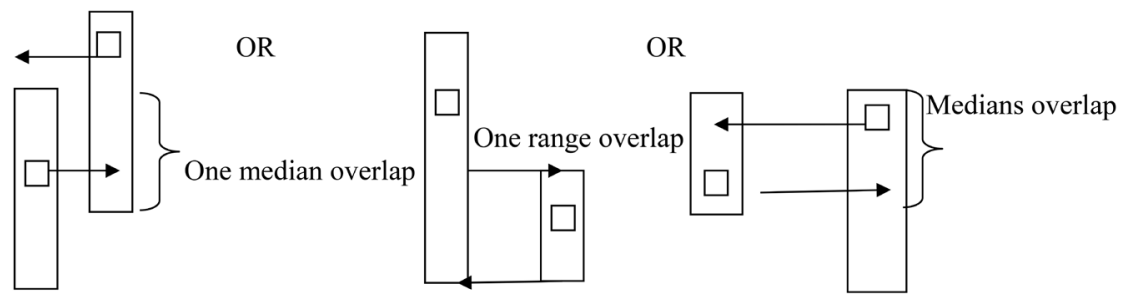

Figure 3. Sensitivity scores of Box-and-Whisker plots according to modified procedures prescribed by Barbour et al. [36], Baptista et al. [9] and Ferreira et al. [38].

\section{4) Spearman's rank correlation test}

For more simplification of the index, a Spearman's rank correlation was drawn with paired orders to eliminate any order if more than $75 \%$ of its values were identical. Orders with Spearman's correlation $\left(r_{s}\right)>0.75$ were considered redundant in which the least abundant order was eliminated [38].

\section{5) More diverse orders ( $n>10$ taxa) criterion}

More diverse orders showing the highest representativeness of organisms distinguishing the reference sites from monitoring sites were chosen and used as potential candidates for developing the BMI. However, the orders were selected to establish the BMI if they had more than 10 families representing a wide range of occurrences and pollution sensitivity.

\section{6) Validation of selected more diverse orders ( $n>10$ taxa)}

A constrained CAP discriminatory analysis and Spearman's rank correlation analysis were used for validating the selected bioindicator orders that showed a wide representativeness of taxa in all sites and ability of distinguishing reference sites from monitoring sites. Spearman's rank correlation analysis was performed by correlating the selected more diverse orders with environmental variables.

\section{Pollution Sensitivity Scoring of Selected Taxa of Bioindicator Orders}

Each identified taxa of the selected macroinvertebrate orders with a potential of developing a biomonitoring method was assigned a pollution sensitivity weighting after an extensive literature review. The sensitivity scores of the reported taxa were assigned based on: 
1) Known scores of taxa extracted from closely related existing indices which have been extensively tested and their capability and reliability for assessing water quality have been proven i.e., SASS5.

2) Autecological knowledge of macroinvertebrate taxa;

3) Association of taxa occurrences or abundances with environmental variables;

4) Simulated results for taxa with unknown sensitive scores to stressors using Canonical Analysis of Principal coordinates (CAP) predictive model.

The CAP predictive model was firstly calibrated by simulating only the abundance of taxa with known scores and their respective scores to facilitate the interpretation of unknown scores. The model was then re-simulated while including all abundances of taxa with their known and unknown sensitivity scores.

\subsection{Data Analysis}

MS Excel, PRIMER ${ }^{\circledR}$ version 7 (with PERMANOVA add-on), OriginPro ${ }^{\circledR}$ version 8.5, Community Analysis Package ${ }^{\circledR}$ version 4 (CAP IV), Species Richness and Diversity IV (SDR IV), and Instat ${ }^{\circledR}$ version 3 (GraphPad ${ }^{\circledR}$ ) software packages were used for analysing the data. Prior to the analysis, all the data were transformed where appropriate and those with different S.I. unit were normalized into unit-less according to Barbour et al. [36], and Baptista et al. [9] in order to maintain uniformity among the values. Significance tests were performed with PRIMER version 7 after the biotic data had undergone transformation (to either $\log (x+1)$, square root, or absent and present), with $p$ value set at 0.05 to determine the differences among basins and site categories. Mann-Whitney $U$ test and Non-Parametric Spearman's rank correlation were performed by Instat ${ }^{\circledR}$ version $3\left(\mathrm{GraphPad}^{\circledR}\right)$ and Box-and-Whisker plots by OriginPro 8.5 used for revealing the discrimination power of the order among the site categories. Canonical Analysis of Principal coordinates (CAP) predictive model was simulated using PERMANOVA+ software package, which is an add-on to PRIMER ${ }^{\circledR}$ version 7 to calculate sensitivity weightings for taxa with unknown sensitivity ratings according to Anderson et al. [39]. Moreover, CAP and non-parametric Spearman's rank correlation analysis were used for validating the ability of taxa to discriminate reference sites from monitoring sites.

\section{Results}

Approximately 97 freshwater macroinvertebrate families belonging to 17 orders were identified collectively to summarize macroinvertebrate data set for Tanzanian rivers (Appendix 4). Six validation criteria (Figure 2) were used for selecting potential orders for use in the biomonitoring index (BMI). The selection criteria included numerical and statistical tests that have been successfully applied in other regions to identify the potential candidates for inclusion during the development of their BMIs. Out of the 17 orders, Ephemeroptera, Diptera, Odonata and Trichoptera (EDOT) were found with significant discriminating power 
separating the reference from impaired sites according to truncate numerical test, Mann-Whitney $U$ test $(\mathrm{p}<0.05)$, Box-and-Whisker plot test, RDA and more diverse orders $(n>10$ taxa) criterion. The rationale for the usefulness of each order is numerically and statistically tested in section 3.1 to 3.9.

\subsection{Truncate Test}

To reduce unusual variability of the data set [37], orders with $\leq 0.5 \%$ of the total macroinvertebrate abundance were numerically exempted for the next screening. Of the 17 macroinvertebrate orders, 10 had abundances of $\geq 0.5 \%$ and thus, passed the truncate numerical test and consequently were retained for the next screening test, with Arhynchobdellida, Rhynchobdellida, Hydroida, Pelecypoda, Megaloptera, Lepidoptera and Turbellaria orders, considered redundant.

\subsection{Mann-Whitney U Test}

Mann-Whitney $U$ test was used for demonstrating the ability of orders to discern the difference between references and monitoring sites of the river basins. Orders were considered strong discriminators of impairment if the difference between monitoring and reference sites was significant (Mann-Whitney U, with $\mathrm{p}<0.05$ ). All the tested orders were found to be non-redundant (with $\mathrm{p}<0.05$ ) and thus considered for the next test (Table 1).

\subsection{Box-and-Whisker Plot Test}

Box-and-Whisker plots were used for evaluating how well each order could discriminate between the site categories, with a sensitivity score of three considered as a selection criterion [36]. The test showed that only six orders were highly sensitive (score $=3$ ) and were consequently retained for non-parametric Spearman's rank correlation selection test. These included: Diptera, Decapoda, Odonata, Ephemeroptera, Coleoptera, and Trichoptera (Table 2 and Figure 4).

Table 1. Results of Mann-Whitney U test for 10 Tanzanian orders of Tanzanian rivers.

\begin{tabular}{cccc}
\hline ORDER & $\begin{array}{c}\text { Mann-Whitney } \\
\text { U test, p-value }\end{array}$ & Test remarks & $\begin{array}{c}\text { Meets the test } \\
\text { criteria }\end{array}$ \\
Tubificida & 0.0186 & Significant & Yes \\
Coleoptera & $<0.0001$ & Extremely significant & Yes \\
Decapoda & 0.0049 & Very significant & Yes \\
Diptera & $<0.0001$ & Extremely significant & Extremely significant \\
Ephemeroptera & $<0.0001$ & Extremely significant & Yes \\
Gastropoda & $<0.0001$ & Extremely significant & Yes \\
Hemi*tera & 0.0001 & Significant & Yes \\
Odonata & 0.0372 & Very significant & Yes \\
Plecoptera & 0.0049 & Extremely significant & Yes \\
Trichoptera & $<0.0001$ & & Yes
\end{tabular}


Table 2. Results of Box-and-Whisker Plot tests for 10 tested orders.

\begin{tabular}{cccc}
\hline ORDER & Response to pollution & Sensitivity score & Meets the test criteria \\
\hline Tubicifida & Decrease & $<2$ & No \\
Coleoptera & Decrease & 3 & Yes \\
Decapoda & Variable & 3 & Yes \\
Gastropoda & Decrease & $<2$ & No \\
Diptera & Increase & 3 & Yes \\
Ephemeroptera & Decrease & 3 & Yes \\
Hemiptera & Decrease & 2 & No \\
Odonata & Increase & 3 & Yes \\
Plecoptera & Decrease & $<2$ & No \\
Trichoptera & Decrease & 3 & Yes \\
\hline
\end{tabular}

\subsection{Spearman's Rank Correlation}

Non-parametric Spearman's rank correlation was used in order to avoid repeating information already summarized by other orders and for ensuring an accurate depiction of patterns by separating reference sites from monitoring sites. Orders with poor range are unlikely to differentiate monitoring and reference sites because the response gradient is highly compressed. Six orders that passed Box-and-Whisker plot tests were tested for redundancy amongst them using Spearman rank correlation analysis. Orders were considered redundant if the Spearman rank correlation coefficient $\left(\mathrm{r}_{\mathrm{s}}\right)$ was higher than 0.75 with a p-value of $<0.05$ [40]. However, all the tested Diptera, Decapoda, Odonata, Ephemeroptera, Coleoptera, and Trichoptera orders were unique with $\mathrm{r}_{\mathrm{s}}$ of $<0.75$ and $\mathrm{p}$ of $<0.05$ and thus, considered non-redundant and were retained for further selection tests.

\subsection{More Diverse Orders ( $n>10$ Taxa) Criterion}

More diverse orders showing the wide representativeness of families in all sites were chosen and used as potential candidates for developing BMI. Ephemeroptera (E), Diptera (D), Odonata $(\mathrm{O})$ and Trichoptera $(\mathrm{T})$ were the only four orders containing large numbers of different taxa $(n>10)$ at all levels of pollution tolerance. Odonata was represented by 12 instances, ephemeropterans by 13 , whereas, dipterans and trichopterans contained 14 instances each, making a total of 53 instances, representing about 55\% ( $\mathrm{N}=97)$ of all Tanzanian taxa.

\subsection{Validation of EDOT Taxa}

A constrained CAP discrimination analysis was performed to analyse macroinvertebrate assemblages for their ability to discern the reference sites from monitoring sites along Tanzanian river basins (Figure 5).

In developing biomonitoring method, it is also important to understand how the selected bio-indicator orders or taxa are correlated with environmental variables. 

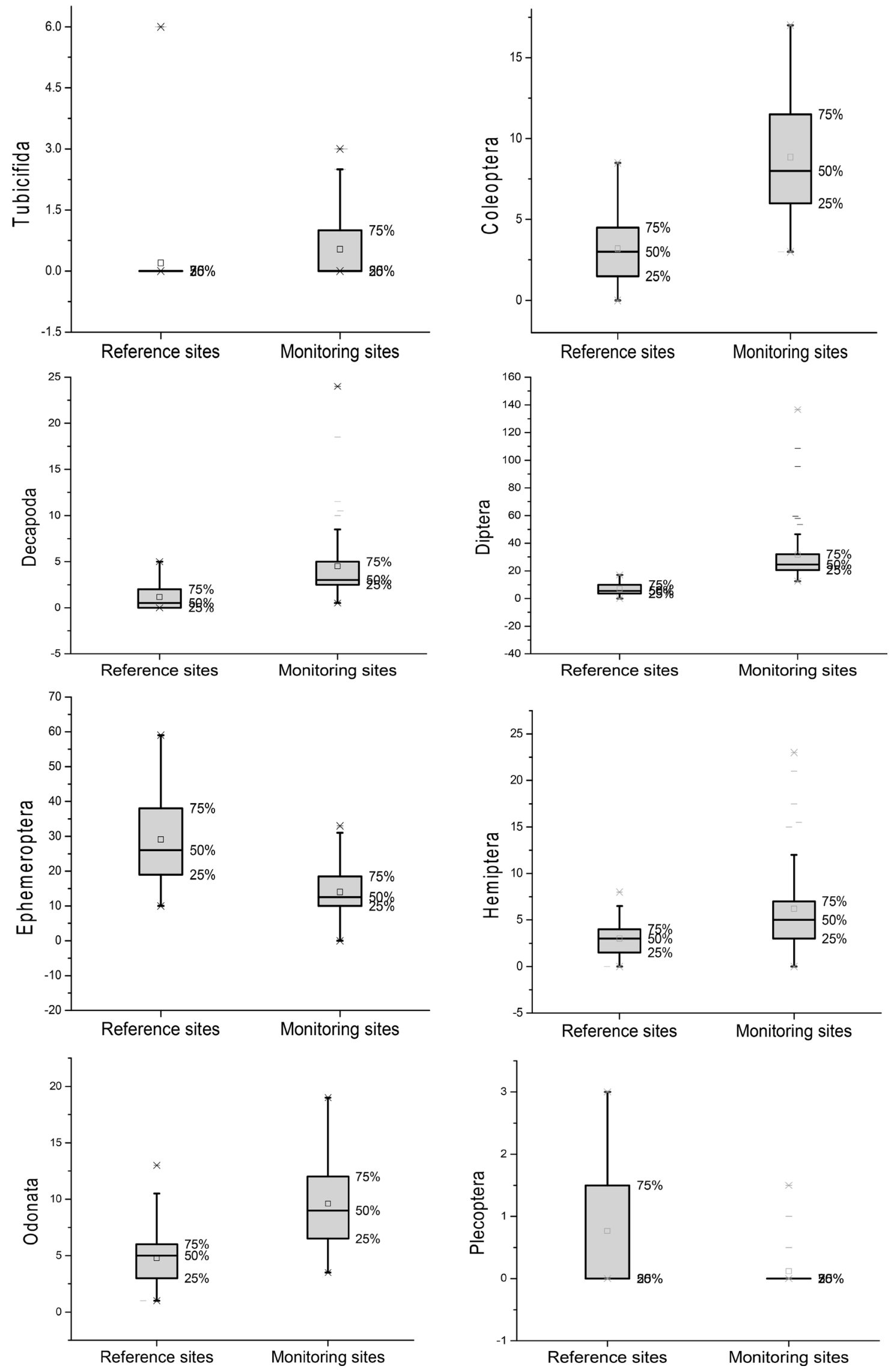

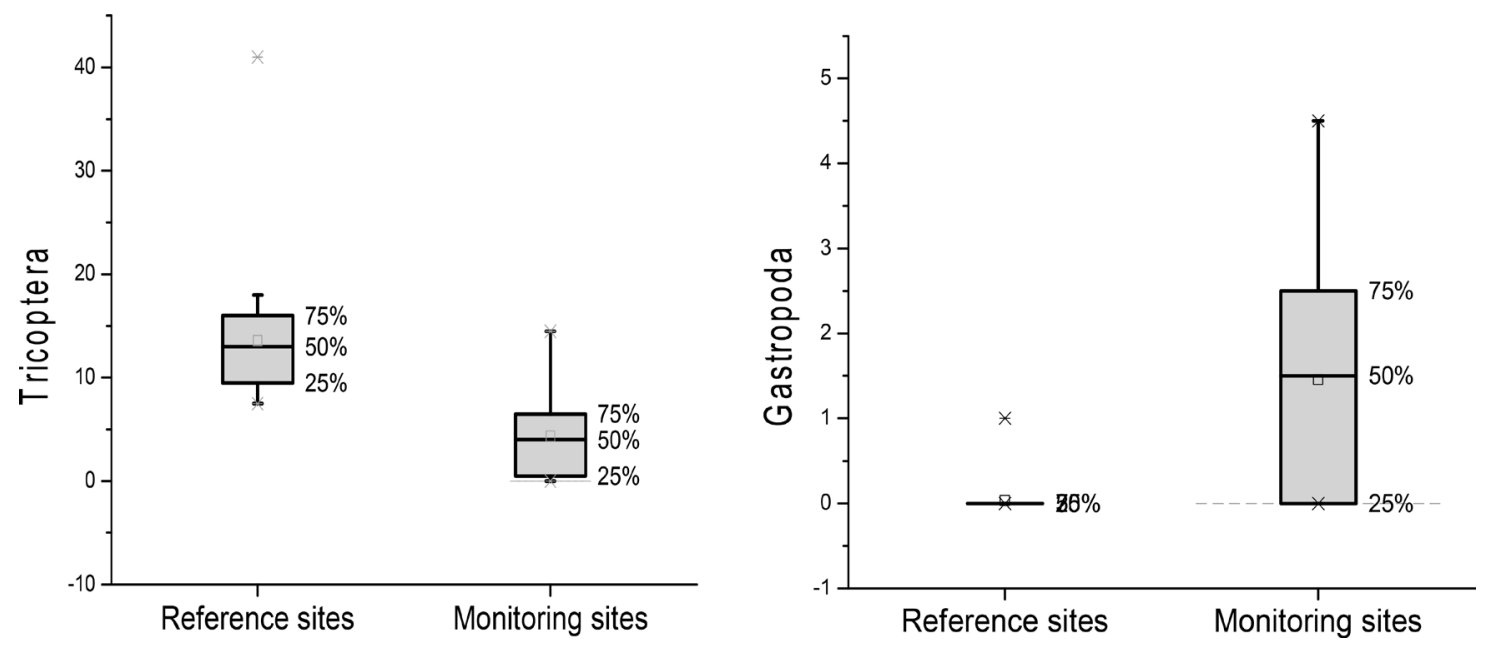

Figure 4. Box-and-Whisker plots for the orders distinguishing reference sites from monitoring sites of Tanzanian river basins.

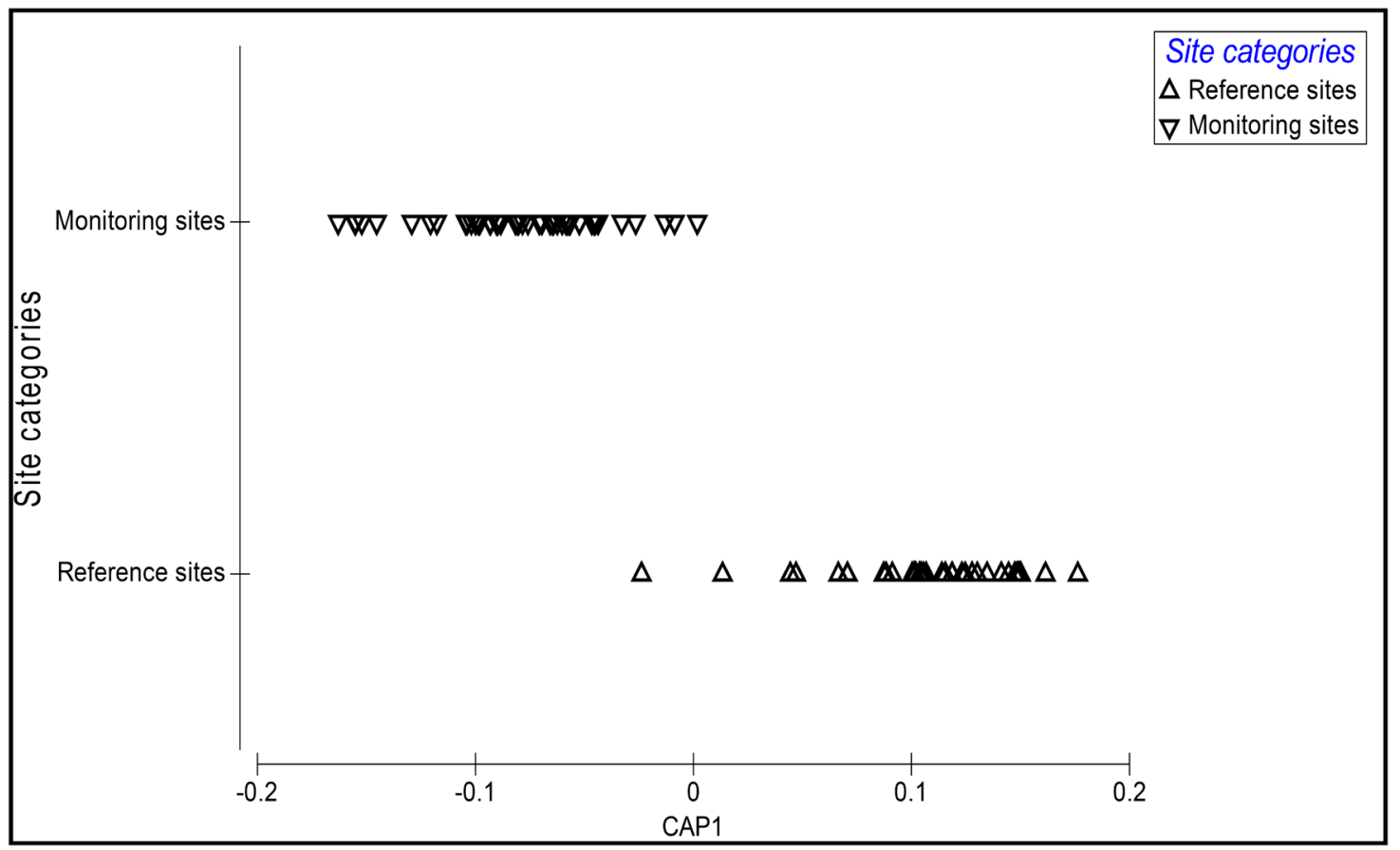

Figure 5. Macroinvertebrate taxa of four selected orders showing their discriminatory power separating reference from monitoring sites using canonical discrimination analysis in Tanzanian river basins $\left(\delta_{2}=0.8479, \mathrm{p}<0.001\right): \mathrm{r}$ $=$ reference sites $; \mathrm{m}=$ monitoring sites.

EDOT taxa were therefore assessed together with various factors that may influence the scores. The results from non-parametric Spearman's rank correlation analysis showed strong significant correlation (with $\mathrm{p}$ of $<0.0001$ ) among the four orders and most environmental variables structuring macroinvertebrate assemblages. Ephemeroptera abundances showed strong correlation with conductivity $\left(r_{s}=-0.4330\right)$ and temperature $\left(r_{s}=-0.4235\right)$; dipterans with conductivity $\left(\mathrm{r}_{\mathrm{s}}=-0.4117\right)$, temperature $\left(\mathrm{r}_{\mathrm{s}}=0.5023\right), \mathrm{NH}_{4}^{+}-\mathrm{N}\left(\mathrm{r}_{\mathrm{s}}=0.6544\right), \mathrm{BOD}\left(\mathrm{r}_{\mathrm{s}}=\right.$ 0.5434), COD $\left(r_{s}=0.6005\right), \quad \mathrm{NO}_{3}^{-}-\mathrm{N} \quad\left(\mathrm{r}_{\mathrm{s}}=0.7399\right), \mathrm{SO}_{4}^{2-} \quad\left(\mathrm{r}_{\mathrm{s}}=0.4914\right)$ and 
potassium $\left(\mathrm{r}_{\mathrm{s}}=0.5734\right)$; Odonata with conductivity $\left(\mathrm{r}_{\mathrm{s}}=0.4098\right)$ and $\mathrm{pH}\left(\mathrm{r}_{\mathrm{s}}=\right.$ 4152), and trichopterans with BOD $\left(r_{s}=-0.5229\right), \operatorname{COD}\left(r_{s}=-0.5492\right)$, $\mathrm{NO}_{3}^{-}-\mathrm{N} \quad\left(r_{s}=0.6278\right), \mathrm{NH}_{4}^{+}-\mathrm{N} \quad\left(r_{s}=-0.5324\right)$ and potassium $\left(r_{s}=-0.4530\right)$. Correlation strength reflects the reliability of the EDOT orders or taxa in detecting changes and/or discriminating the reference sites from monitoring sites along the rivers in the two basins. Since EDOT taxa have demonstrated their ability to discern the reference sites from monitoring sites via CAP and Spearman's rank correlation analysis, they can therefore be used as potential bio-indicators in developing EDOT method.

\subsection{Scoring of Selected Bioindicator Taxa}

Generally, the sensitivity scores ranged from zero to 15, representing three categories of macroinvertebrate groups. Sensitivity scores for most tolerant taxa to stressors ranged from 11 to 15 , whereas, six to 10 is for moderately tolerant taxa, and one to five for the least tolerant taxa [41]. If the species vary within taxa (i.e., Baetidae or Hydropsychidae) their sensitivity scores were assigned under the descending assumption that the more the species available at a site the less disturbed the site is, as such, a sensitivity rating of four is given to Baetidae 1 species, six to Baetidae 2 species and 12 to Baetidae $>2$ species [42]. Of the 53 taxa, 50 were assigned scores based on related scoring systems [12] [14] [17] [42] while the sensitivity scores for the remaining three taxa were simulated by the CAP predictive model (Figure 6). The CAP predictive model with a correlation of 0.8543 and/or correlation square $\left(\delta^{2}=0.7299\right)$ calculated sensitivity scores for Dicercomyzidae, Ephemerythidae and Macromiidae as $9.7246 \approx 10 ; 8.8258 \approx 9$ and $3.1 \approx 3$ respectively (Figure 6 ).

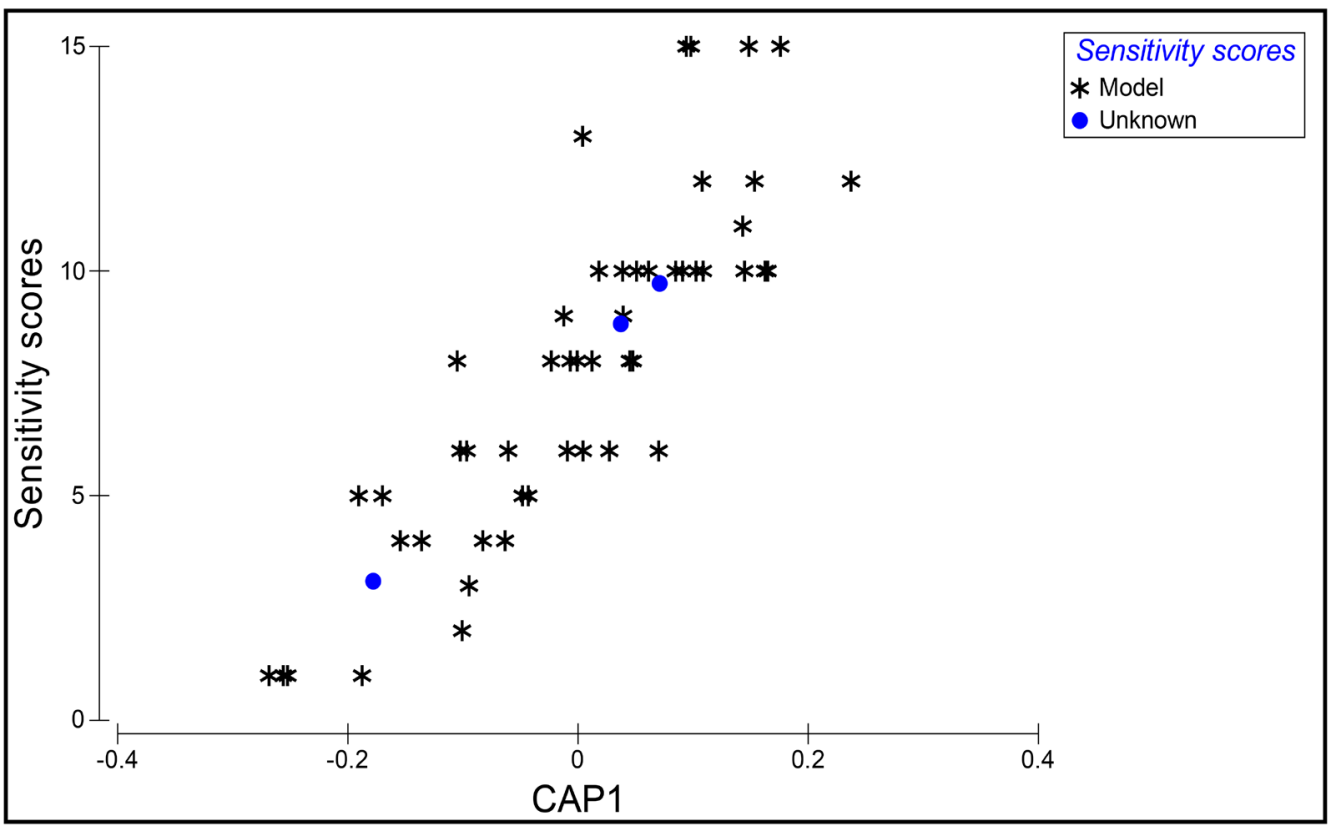

Figure 6. Canonical Analysis of Principal coordinates (CAP) predictive model showing the position of taxa in relation to their sensitivity scores. 


\subsection{Application of EDOT Index (Calculating EDOT Index)}

EDOT index (Appendix 1) is a field based rapid scoring system entailing in situ observation (with the help of $10 \times 45$ magnifying stereo microscope were deemed necessary), in which taxa are identified up to family level. Regardless of its abundance, each observed taxon is estimated upon observation and tallied in their respective biotope (stone, vegetation and GSM) and the combined column one of EDOT scoring sheet. A single macroinvertebrate is estimated as one organism whereas, less than one to 10 organisms as two, $>10$ to 100 as three, $>100$ to 1000 as four and $>1000$ as five in order to minimize scoring time. Time less than 10 minutes per site is recommended to end the fieldwork but if there is not any observed taxon in the duration of one minute.

The ticked sensitivity score of each taxon in the combined column is summed up to provide an $\operatorname{EDOT}(\mathrm{f})$ score, whereas, the total number of taxa is obtained by counting the recorded taxa. ASPT, on the other hand, is calculated by dividing the EDOT(f) scores by the number of taxa. EDOT Index can be calculated as EDOT(f) Score, Number of Taxa (No. Taxa) and Average Score per Taxa (ASPT) but only the result calculated from the combined column will represent the EDOT result for that particular site.

Mathematically, $\operatorname{EDOT}(\mathrm{f})$ is calculated as:

$$
\operatorname{EDOT}(\mathrm{f})=\sum_{i=1}^{n} \text { Score }_{i}
$$

The Average Score Per Taxon (ASPT) is calculated by dividing EDOT(f) scores by the total number of taxa found as follows.

$$
\mathrm{ASPT}=\frac{\sum_{i=1}^{n} \text { Score }_{i}}{n}
$$

where: Score $_{i}$ stands for the score of taxon $i$ and $n$ for the number of taxa.

Moreover, separate results may be achieved for each biotope and used in various investigations, only the result calculated from the total column will represent the EDOT(f) result for a site. Since this new index is designed to describe the degree at which tropical African riverine systems are impacted by human induced pollution, the scores towards zero represent stressed river while towards 100 refers to unstressed river. However, Dickens and Graham [12] have cautioned on the implication of combining the scores from the three biotopes by adding the score of any index, the number of taxa and ASPT and dividing the total by three. The resulting EDOT(f) score and ASPT score are interpreted using modified threshold values in Table 3.

\section{Discussion}

A 15-sensitivity scoring range following SASS5 [12], ETHbios [42] and TARISS [17] was used for all identified families of selected orders. Out of the total 97 taxa recorded from all sites, scores were assigned to only 53 taxa that showed clear water quality preferences, using either closely related earlier indices (50 taxa) or 
Table 3. The suggested EDOT(f) threshold limits for assessing river health status.

\begin{tabular}{|c|c|c|c|c|}
\hline \multicolumn{2}{|c|}{ BAND BOUNDARY } & \multirow{2}{*}{ BIOLOGICAL BAND } & \multirow{2}{*}{$\begin{array}{l}\text { DESCRIPTION } \\
\text { Impairment Level }\end{array}$} & \multirow{2}{*}{$\begin{array}{l}\text { WATER STATUS } \\
\text { Water Quality }\end{array}$} \\
\hline EDOT Score & ASPT Score & & & \\
\hline$\leq 50$ & $\leq 5.0$ & Seriously Modified & Serious ecological impairment & Very poor water quality \\
\hline 51 to 75 & 5.1 to 6.0 & Largely Modified & Large ecological impairment & Poor water quality \\
\hline 76 to 150 & 6.1 to 7.0 & Moderately Modified & Moderate ecological impairment & Moderate water quality \\
\hline 151 to 225 & 7.1 to 8.0 & Largely Natural & Slight ecological impairment & Good water quality \\
\hline$>225$ & $>8.0$ & Natural & Little ecological impairment & High water quality \\
\hline
\end{tabular}

CAP predictive model (three taxa). However, a flexible consideration was applied to assigning sensitivity scores for specific taxa groups with a number of types i.e., Baetidae (with 1 sp., 2 spp. and >2 spp.), and Hydropsychidae (1 sp., 2 spp. and $>2$ spp.) that cover wide pollution gradients [42] in order to increase the discrimination efficiency of these taxa among site categories.

The sensitivity scores for the taxa obtained from earlier indices strongly support the simulated CAP predictive model results with some families of the same order found matching the scores. For instance, the calculated score of 10 for Dicercomyzidae concurs with that of Polymitarcyidae whereas the score of nine awarded to Leptophlebiidae and Tricorythidae by earlier studies was at par with that simulated for Ephemerythidae (nine). Contrary to Dicercomyzidae and Ephemerythidae, Macromiidae was the least sensitive taxon (with a score of three) compared to the other Odonata families but close to the sensitive score of four, which was reported for Coenagrionidae and Libellulidae by existing biomonitoring methods. According to Gerber and Gabriel [41], the simulated sensitivity scores for Dicercomyzidae (10) and Ephemerythidae (nine) fall well within the range of moderately sensitive taxa while the Macromiidae (three) is grouped with the least sensitive taxa along the y-axis in Figure 6. The varied sensitivity levels to human stressors allow families of the EDOT orders to function as bio-indicators for assessing freshwater health status with strong relevance on conservation and management aspects [43].

Validation criteria, which included six selection criteria, were also set during the selection of orders to be involved in developing the index for the sake of simplifying taxonomic complications and improving the accuracy and efficiency of the index while minimizing the data collection time and cost. Indeed, EDOT orders are well known as more diverse and abundant orders in freshwater ecosystems with a large number of taxa and species [44] [45] [46], varied degrees of sensitivity to a wide range of anthropogenic stressors [47] and a recognizable contribution in the biomonitoring programmes [48]. In the presence of various environmental stress types i.e., organic pollution [49], heavy metals [50], hydro-morphological degradation [51], nutrient enrichment [52], acidification [53] and general stressors [8], their families can collectively reflect short and long-term health status of aquatic ecosystems [9]. However, 13 other orders were eliminated because they either failed to reflect the different features of freshwater 
macroinvertebrates communities or discriminating reference sites from monitoring sites according to truncate numerical test, the Mann-Whitney $U$ test (with $\mathrm{p}<0.05$ ), Box-and-Whisker plot test, Non-parametric Spearman's rank correlation test and more diverse taxa $(n>10)$ criteria. Similarly, the presence of cryptic species (e.g., chironomids) with varied responses towards pollution, and some being rarely identified to the species level [46] has restricted the development of species level EDOT index. Moreover, the lowest taxonomical unit identification has cost and time bound implications, and also requires more specialized knowledge and expertise [2] [42] [54]. However, the sensitivity variation for some families of the same order might contradict the biomonitoring efforts. For example, the Odonata family Gomphidae, has been classified among the most sensitive taxa whereas Coenagrionidae is far less sensitive to pollution [55].

Ephemeropterans are considered as ecologically an important order in biomonitoring programmes all over the world due to their least tolerant character against low dissolved oxygen, higher levels of nutrients, and toxicant chemical elements and compounds [56]. The order is abundantly found in sites with good water quality at interstitial spaces between rocks, rock surfaces, sediments, submerged underwater and marginal vegetation, with high amount of dissolved oxygen [56].

Contrary to Ephemeroptera, Trichoptera are somewhat more tolerant to pollution, but do not persist as a diverse community in the presence of significant impairment [57]. Trichopterans on the other hand inhabit a wide variety of habitats, ranging from fast flowing riffles to slow moving water type of sparsely vegetated pools. Being diverse, abundant and able to thrive in lentic conditions of both slow and fast-moving rivers makes them excellent indicators of habitat quality [57]. Regardless of their reported inconsistent nature in detecting impacts [48], the inclusion of trichopterans in biomonitoring programmes is not only virtual in evaluating the long-term interaction of several environmental conditions, but also in detecting short-term impact.

The strong significant correlation (with $\mathrm{p}<0.0001$ ) shown between the EDOT orders and most of the environmental variables structuring macroinvertebrate assemblages indicates better performance of the orders to organic pollution. In polluted rivers, abundance and diversity of more sensitive orders (ephemeropterans and trichopterans) are strongly reduced due to direct and indirect impact of pollutants where dipterans commonly possess the dominant status. The ability of dipterans to survive well in highly polluted freshwater environment and in slow moving water than most of the ephemeropterans, trichopterans and Odonata, render them good indicators for assessment of aquatic health status [58]. EDOT has ensured response of overall ecological status in river basins by segregating reference sites from monitoring sites and thus, concurring with other studies in the U.S.A [36], Europe [59], Brazil [9], and Tanzania [17].

\section{Conclusion}

The study has provided the first simplified biomonitoring method comprised of 
local based macroinvertebrate taxa with a wide range of occurrences, trophic levels and sensitivity to pollution as a tool for assessing water pollution in tropical African rivers. Being developed using only a few (four) and more diverse orders (with $>10$ taxa), minimizes data variability, needs for greater expertise and time in the field and thus makes it a less complex method than existing biomonitoring methods. A high EDOT method score describes an ecosystem containing diversified physical habitats, good water quality with conducive physicochemical conditions and adequate food resources for sustaining the lives of many species. This method is also in line with the interest shown by African and non-African environmental and water quality monitoring institutions and/or authorities in the application of biomonitoring methods, which tend to be lower cost and more effective than physical-chemical methods [18] [46], with emphasis on regionally or country-based water quality biomonitoring programmes. Upon validation, the resulting EDOT index can therefore be regarded as simple and cost-effective tool for assessing the ecological condition in Tanzanian rivers and other related watersheds in tropical African regions, where freshwater resources are under high pressure as a result of anthropogenic activities.

\section{Acknowledgements}

The authors would like to thank the Nelson Mandela African Institute of Science and Technology (NM-AIST) for their support during the field work and the Department of Aquatic Sciences and Fisheries Laboratory of the University of Dar es Salaam for space during the analysis of chemical parameters.

\section{Funding}

This study received financial support from Nelson Mandela Foundation through Tanzania Commission for Science and Technology (COSTECH).

\section{Conflicts of Interest}

The author declares no conflicts of interest regarding the publication of this paper.

\section{References}

[1] Umar, D.M., Harding, J.S. and Winterbourn, M.J. (2013) Freshwater Invertebrates of the Mambilla Plateau, Nigeria. Gombe State University and University of Canterbury, Christchurch, $88 \mathrm{p}$.

[2] Elias, J.D., Ijumba, J.N. and Mamboya, F.A. (2014) Effectiveness and Compatibility of Non-Tropical Biomonitoring Indices for Assessing Pollution in Tropical Rivers-A Review. International Journal of Ecosystem, 4, 128-134. https://doi.org/10.1155/2014/985389

[3] Elias, J.D., Ijumba, J.N., Mgaya, Y.D. and Mamboya, F. (2014) Study on Freshwater Macroinvertebrates of Some Tanzanian Rivers as a Basis for Developing Biomonitoring Index for Assessing Pollution in Tropical African Regions. Journal of Ecosystems, 2014, Article ID: 985389. https://doi.org/10.1155/2014/985389

[4] Chutter, F.M. (1972) An Empirical Biotic Index of the Quality of Water in South 
African Streams and Rivers. Water Research, 6, 19-30. https://doi.org/10.1016/0043-1354(72)90170-4

[5] Wright, J.F., Moss, D., Armitage, P.D. and Furse, M.T. (1984) A Preliminary Classification of Running-Water Sites in Great Britain Based on Macroinvertebrate Species and Prediction of Community Type Using Environmental Data. Freshwater Biology, 14, 221-256. https://doi.org/10.1111/j.1365-2427.1984.tb00039.x

[6] Hawks, H.A. (1997) Origin and Development of the Biological Monitoring Working Party System. Water Research, 32, 964-968. https://doi.org/10.1016/S0043-1354(97)00275-3

[7] Chutter, F.M. (1998) Research on the Rapid Biological Assessment of Water Quality Impacts in Streams and Rivers. Water Research Commission Report No. 422/1/98. Water Research Commission, Pretoria.

[8] Barbour, C.D.M.T., Gerritsen, J., Snyder, B.D. and Stribling, J.B. (1999) Rapid Bioassessment Protocols for Use in Streams and Wadeable Rivers: Periphyton, Benthic Macroinvertebrates and Fish; 2nd Edition. EPA 841-B-99-002. U.S. Environmental Protection Agency, Office of Water, Washington DC.

[9] Baptista, D.F., Buss, D.F., Egler, M., Giovanelli, A., Silveira, M.P. and Nessimian, J.L. (2007) A Multimetric Index Based on Benthic Macroinvertebrates for Evaluation of Atlantic Forest Streams at Rio de Janeiro State, Brazil. Hydrobiologia, 575, 83-94. https://doi.org/10.1007/s10750-006-0286-x

[10] Jacobsen, D. and Marın, R. (2007) Bolivian Altiplano Streams with Low Richness of Macroinvertebrates and Large Diel Fluctuations in Temperature and Dissolved Oxygen. Aquatic Ecology, 42, 643-656. https://doi.org/10.1007/s10452-007-9127-x

[11] Day, J.A. (2000) Biomonitoring: Appropriate Technology for the 21st Century. 1 st WARFSA/ WaterNet Symposium: Sustainable Use of Water Resources, Maputo, 7 p.

[12] Dickens, C.W.S. and Graham, P.M. (2002) The South African Scoring System (SASS) Version 5 Rapid Bioassessment Method for Rivers. African Journal of Aquatic Science, 27, 1-10. https://doi.org/10.2989/16085914.2002.9626569

[13] Dallas, H.F., Kennedy, M., Taylor, J., Lowe, S. and Murphy, S. (2010) SAFRASS. South African Rivers Assessment Scheme, WP4. Review Paper. 39 p.

[14] Palmer, R.W. and Taylor, E.D. (2004) The Namibian Scoring System (NASS) Version 2 Rapid Bioassessment Method for Rivers. African Journal of Aquatic Science, 29, 229-234. https://doi.org/10.2989/16085910409503814

[15] Dallas, H.F. (2009) Wetland Monitoring Using Aquatic Macroinvertebrates. Technical Report. Report 5/2009 Prepared for the Biokavango Project, Harry Oppenheimer Okavango Research Centre, University of Botswana, The Freshwater Consulting Group, University of Cape Town, Cape Town, 27 p.

[16] Lowe, S., Dallas, H., Kennedy, M., Taylor, J.C., Gibbins, C., Lang, P., Day, J., Sichingabula, H., Saili, K., Willems, F., Briggs, J.A. and Murphy, K. (2013) The SAFRASS Biomonitoring Scheme: General Aspects, Macrophytes (ZMTR) and Benthic Macroinvertebrates (ZISS) Protocols. Produced for the ACP Science and Technology Programme. 16 p.

[17] Kaaya, L.T. (2015) Towards a Classification of Tanzanian Rivers: A Bioassessment and Ecological Management Tool. A Case Study of the Pangani, Rufiji and Wami-Ruvu River Basins. African Journal of Aquatic Science, 40, 37-45. https://doi.org/10.2989/16085914.2015.1008970

[18] Aschalew, L. (2014) Development of Biological Monitoring Systems Using Benthic Invertebrates to Assess the Ecological Status of Central and South-East Highland Rivers of Ethiopia. Unpublished Thesis for Award of PhD Degree at University of 
Natural Resources and Life Sciences, Vienna, 163 p.

[19] Boulton, A.J., Boyero, L., Covich, A.P., Dobson, M., Lake, S. and Pearson, R. (2008) Are Tropical Streams Ecologically Different from Temperate Streams? In: Dudgeon, D., Ed., Tropical Stream Ecology, Elsevier Inc., London, 257-284. https://doi.org/10.1016/B978-012088449-0.50011-X

[20] Pearson, R.G. and Boyero, L. (2009) Gradients in Regional Diversity of Freshwater Taxa. Journal of the North American Benthological Society, 28, 504-514. https://doi.org/10.1899/08-118.1

[21] Jacobsen, D., Cressa, C., Mathooko, J.M. and Dudgeon, D. (2008) Macroinvertebrates: Composition, Life Histories and Production. In: Dudgeon, D., Ed., Tropical Stream Ecology, Academic Press, Cambridge, 66-96. https://doi.org/10.1016/B978-012088449-0.50006-6

[22] Masese, F.O., Muchiri, M. and Raburu, P.O. (2010) A Preliminary Benthic Macroinvertebrate Index of Biotic Integrity (B-IBI) for Monitoring the Moiben River, Lake Victoria, Kenya. African Journal of Aquatic Science, 34, 1-14. https://doi.org/10.2989/AJAS.2009.34.1.1.726

[23] Blakely, T.J., Harding, J.S., Clews, E. and Winterbourn, M.J. (2010) An Illustrated Guide to the Freshwater Macroinvertebrates of Singapore. School of Biological Sciences, University of Canterbury, Christchurch, $74 \mathrm{p}$.

[24] Ngupula, G.W. and Kayanda, R. (2010) Benthic Macrofauna Community Composition, Abundance and Distribution in the Tanzania and Uganda Inshore and Offshore Waters of Lake Victoria. African Journal of Aquatic Science, 35, 185-192. https://doi.org/10.2989/16085914.2010.490978

[25] APHA (2000) Standard Methods for the Analysis of Water and Wastewater. 15th Edition, American Public Health Association and Water Pollution Control Federation, Washington DC, 12-56.

[26] Wetzel, R.G. and Linkens, G. (2000) Limnological Analyses. Springer (India) Publisher Private Limited, New Delhi, 426 p. https://doi.org/10.1007/978-1-4757-3250-4

[27] Day, J.A., de Moor, I.J., Stewart, B.A. and Louw, A.E. (2001) Guides to the Freshwater Invertebrates of Southern Africa: Volume 3 Crustacea II-Ostracoda, Copepoda and Branchiura. WRC Report No. TT 148/01. Water Research Commission, Pretoria, $177 \mathrm{p}$.

[28] Day, J.A., de Moor, I.J., Stewart, B.A. and Louw, A.E. (2001) Guides to the Freshwater Invertebrates of Southern Africa: Volume 4 Crustacea III-Bathynellacea, Amphipoda, Isopoda, Spelaeogriphea, Tanaidacea and Decapoda. WRC Report No. TT 141/01. Water Research Commission, Pretoria, 126 p.

[29] Thorn, J.H. and Covich, A.P. (1991) Ecology and Classification of North American Freshwater Invertebrates. Academic Press, San Diego, 1056 p.

[30] Day, J.A. and De Moor, I.J. (2002) Guides to the Freshwater Invertebrates of Southern Africa: Volume 6 Arachnida and Mollusca-Araneae, Water Mites and Mollusca. WRC Report No. TT 182/02. Water Research Commission, Pretoria, 141 p.

[31] Day, J.A. and De Moor, I.J. (2002) Guides to the Freshwater Invertebrates of Southern Africa: Volume 5 Non-Arthropods-The Protozoans, Porifera, Cnidaria, Platyhelminthes, Nemertea, Rotifera, Nematoda, Nematomorpha, Gastrotrichia, Bryozoa, Tardigrada, Polychaeta, Oligochaeta and Hirudinea. WRC Report No. TT 167/02. Water Research Commission, Pretoria, 293 p.

[32] Day, J.A., Harrison, A.D. and de Moor, I.J. (2003) Guides to the Freshwater Invertebrates of Southern Africa: Volume 9 Diptera. WRC Report No. TT 201/02. Water Research Commission, Pretoria, 288 p. 
[33] De Moor, I.J., Day, J.A. and De Moor, F.C. (2003) Guides to the Freshwater Invertebrates of Southern Africa: Volume 7 Insecta I-Ephemeroptera, Odonata and Plecoptera. WRC Report No. TT 207/03. Water Research Commission, Pretoria, $288 \mathrm{p}$.

[34] De Moor, I.J., Day, J.A. and De Moor, F.C. (2003) Guides to the Freshwater Invertebrates of Southern Africa: Volume 8 Insecta II-Hemiptera, Megaloptera, Neuroptera, Trichoptera and Lepidoptera. WRC Report No. TT 214/03. Water Research Commission, Pretoria, $209 \mathrm{p}$.

[35] Stals, R. and De Moor, I.J. (2007) Guides to the Freshwater Invertebrates of Southern Africa: Volume 7 Insecta I-Ephemeroptera, Odonata and Plecoptera. WRC Report No. TT 320/07, Water Research Commission, Pretoria, 263 p.

[36] Barbour, M.T. and Gerritsen, J. (1996) Sub Sampling of Benthic Samples: A Defense of the Fixed-Count Method. Journal of the North American Benthological Society, 15, 386-391. https://doi.org/10.2307/1467285

[37] Gauch, H.G. (1982) Multivariate Analysis in Community Ecology. Cambridge University Press, Cambridge, 307 p. https://doi.org/10.1017/CBO9780511623332

[38] Ferreira, W.R., Paiva, L.T. and Callisto, M. (2011) Development of a Benthic Multimetric Index for Biomonitoring of a Neotropical Watershed. Brazil Journal of Biology, 71, 15-25. https://doi.org/10.1590/S1519-69842011000100005

[39] Anderson, M.J., Gorley, R.N. and Clarke, K.R. (2008) PERMANOVA + for PRIMER: Guide to Software and Statistical Methods. The University of Auckland, Plymouth, $214 \mathrm{p}$.

[40] Whittier, T.R., Stoddard, J.L., Larsen, D.P. and Herlihy, A.T. (2007) Selecting Reference Sites for Stream Biological Assessments: Best Professional Judgment or Objective Criteria. Journal of the North American Benthological Society, 26, 349-360. https://doi.org/10.1899/0887-3593(2007)26[349:SRSFSB]2.0.CO;2

[41] Gerber, A. and Gabriel, M.J.M. (2002) Aquatic Invertebrates of South African Rivers. Field Guide. Institute for Water Quality Studies, Vol. I and II, 150 p.

[42] Aschalew, L. and Moog, O. (2015) A Multimetric Index Based on Benthic Macroinvertebrates for Assessing the Ecological Status of Streams and Rivers in Central and Southeast Highlands of Ethiopia. Hydrobiologia, 751, 229-242. https://doi.org/10.1007/s10750-015-2189-1

[43] Hornung, J.P. and Rice, C.L. (2003) Odonata and Wetland Quality in Southern Alberta, Canada: A Preliminary Study. Odonata, 32, 119-129.

[44] Hofmann, T.A. and Mason, C.F. (2005) Habitat Characteristics and the Distribution of Odonata in a Lowland River Catchment in Eastern England. Hydrobiologia, 539, 137-147. https://doi.org/10.1007/s10750-004-3916-1

[45] Hughes, S.J. (2006) Temporal and Spatial Distribution Patterns of Larval Trichoptera in Madeiran Streams. Hydrobiologia, 553, 27-41.

https://doi.org/10.1007/s10750-005-0627-1

[46] Mereta, S., Boetsa, P., De Meesterc, L. and Goethalsa, P.L.M. (2013) Development of a Multimetric Index Based on Benthic Macroinvertebrates for the Assessment of Natural Wetlands in Southwest Ethiopia. Ecological Indicators, 29, 510-521. https://doi.org/10.1016/j.ecolind.2013.01.026

[47] Verdonschot, R.C.M., Keizer-Vlek, H.E. and Verdonschot, P.F.M. (2012) Development of a Multimetric Index Based on Macroinvertebrates for Drainage Ditch Networks in Agricultural Areas. Ecological Indicators, 13, 232-242. https://doi.org/10.1016/j.ecolind.2011.06.007

[48] Kashian, D.R. and Burton, T.M. (2000) A Comparison of Macroinvertebrates of 
Two Great Lakes Coastal Wetlands: Testing Potential Metrics for an Index of Ecological Integrity. Journal of Great Lakes Research, 26, 460-548.

https://doi.org/10.1016/S0380-1330(00)70708-8

[49] Zamora-Muñoz, C. and Alba-Tercedor, J. (1996) Bioassessment of Organically Polluted Spanish Rivers, Using a Biotic Index and Multivariate Methods. Journal of the North American Benthological Society, 15, 332-352. https://doi.org/10.2307/1467281

[50] Smolders, A.J.P., Lock, R.A.C, Van der Velde, G., Medina Hoyos, R.I. and Roelofs, J.G.M. (2003) Effects of Mining Activities on Heavy Metal Concentrations in Water, Sediment and Macroinvertebrates in Different Reaches of the Pilcomayo River, South America. Archives of Environmental Contamination and Toxicology, 44, 314-323. https://doi.org/10.1007/s00244-002-2042-1

[51] Lorenz, A., Hering, D., Feld, C.K. and Rolauffs, P. (2004) A New Method for Assessing the Impact of Hydromorphological Degradation on the Macroinvertebrate Fauna of Five German Stream Types. Hydrobiologia, 516, 107-127.

https://doi.org/10.1007/978-94-007-0993-5_7

[52] Johnson, R.K., Hering, D., Furse, M.T. and Verdonschot, P.F.M. (2006) Indicators of Ecological Change: Comparison of the Early Response of Four Organism Groups to Stress Gradients. Hydrobiologia, 566, 139-152.

https://doi.org/10.1007/s10750-006-0100-9

[53] Sandin, L. and Johnson, R.K. (2000) The Statistical Power of Selected Indicator Metrics Using Macroinvertebrates for Assessing Acidification and Eutrophication of Running Waters. Hydrobiologia, 422-423, 233-243. https://doi.org/10.1007/978-94-011-4164-2_19

[54] Schmidt-Kloiber, A. and Nijboer, R.C. (2004) The Effect of Taxonomic Resolution on the Assessment of Ecological Water Quality Classes. Hydrobiologia, 516, 269-283. https://doi.org/10.1007/978-94-007-0993-5_16

[55] Foote, A.L. and Hornung, C.L.R. (2005) Odonates as Biological Indicators of Grazing Effects on Canadian Prairie Wetlands. Ecological Entomology, 30, 273-283. https://doi.org/10.1111/j.0307-6946.2005.00701.x

[56] Arimoro, F.O. and Muller, W.J. (2010) Mayfly (Insecta: Ephemeroptera) Community Structure as an Indicator of the Ecological Status of a Stream in the Niger Delta Area of Nigeria. Environmental Monitoring and Assessment, 166, 581-594. https://doi.org/10.1007/s10661-009-1025-3

[57] Houghton, D.C. (2004) Biodiversity of Minnesota Caddisflies (Insecta: Trichoptera): Delineation and Characterization of Regions. Environmental Monitoring and Assessment, 95, 153-181. https://doi.org/10.1023/B:EMAS.0000029890.07995.90

[58] Shelly, S.Y., Mirza, Z.B. and Bashir, S. (2011) Comparative Ecological Study of Aquatic Macroinvertebrates of Mangla Dam and Chashma Barrage Wetland Areas. Journal of Animal and Plant Science, 21, 340-350.

[59] Pinto, P., Rosado, J., Morais, M. and Antunes, I. (2004) Assessment Methodology for Southern Siliceous Basins in Portugal. Hydrobiologia, 516, 191-214.

https://doi.org/10.1007/978-94-007-0993-5_12 


\section{Appendix}

\section{Appendix 1: The new EDOT Index developed under Tanzanian riverine conditions}

\begin{tabular}{|c|c|c|c|c|c|c|c|}
\hline DESCRIPTION OF PHYSICAL ENVIRONMENT & & & OOT(f) IN & & & & \\
\hline EDOT Index Version 1 Score Sheet @2015 & Order & Family & Scores & $\mathbf{S}$ & MV & GSM & TOT \\
\hline Date:_........../.............../20............; Time:............................. & Ephemeroptera & Baetidae $1 \mathrm{sp}$. & 4 & & & & \\
\hline Operator: & & Baetidae $2 \mathrm{spp}$. & 6 & & & & \\
\hline 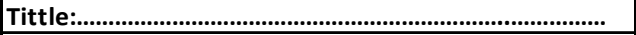 & & Baetidae $>2 \mathrm{spp}$ & 12 & & & & \\
\hline 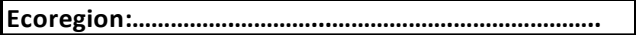 & & Caenidae & 6 & & & & \\
\hline 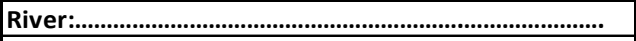 & & Dicercormyzidae & 10 & & & & \\
\hline Site Code: & & Ephemeridae & 15 & & & & \\
\hline Latitudes: S:........................................',,..........................." & & Ephemerythidae & 9 & & & & \\
\hline Longitudes: E:..................... , ,....................',,..........................." & & Heptageniidae & 13 & & & & \\
\hline Altitude:_................................................................m a.s.I & & Leptophlebiidae & 9 & & & & \\
\hline Slope @ Left bank:...............\%; Right bank:.................\% & & Oligoneuridae & 15 & & & & \\
\hline 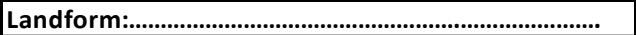 & & Polymitarcyidae & 10 & & & & \\
\hline 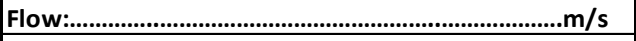 & & Potomanthidae & 10 & & & & \\
\hline Temp: & & Prosopistomatidae & 15 & & & & \\
\hline pH:ANon, & & Tricorythidae & 9 & & & & \\
\hline 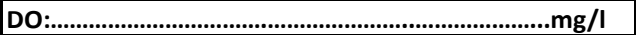 & Diptera & Athericidae & 10 & & & & \\
\hline 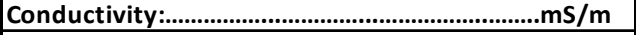 & & Blephariceridae & 15 & & & & \\
\hline Turbidity:...................................................................NTU & & Ceratopogonidae & 5 & & & & \\
\hline Site Description: & & Chironomidae & 2 & & & & \\
\hline & & Culicidae & 1 & & & & \\
\hline & & Dixidae & 10 & & & & \\
\hline & & Empididae & 6 & & & & \\
\hline Instream Disturbance: & & Ephydridae & 3 & & & & \\
\hline & & Muscidae & 1 & & & & \\
\hline & & Psychodidae & 1 & & & & \\
\hline & & Simuliidae & 5 & & & & \\
\hline Riparian Land Use: & & Syrphidae & 1 & & & & \\
\hline & & Tabanidae & 5 & & & & \\
\hline & & Tipulidae & 5 & & & & \\
\hline & Odonata & Aeshnidae & 8 & & & & \\
\hline & & Calopterygidae & 10 & & & & \\
\hline & & Chlorocyphidae & 10 & & & & \\
\hline Stone In Currenct (SIC) sampling time $(\min ): \ldots . . . \ldots \ldots \ldots . . . . . . .$. & & Chlorolestidae & 8 & & & & \\
\hline Stone Out Of Current (SOOC) sampling time (min):.... & & Coenagrionidae & 4 & & & & \\
\hline 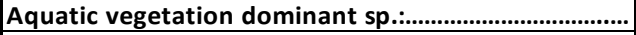 & & Corduliidae & 8 & & & & \\
\hline Marginal Vegetation In Current Dominant sp:............. & & Gomphidae & 6 & & & & \\
\hline Marginal Vegetation Out Of Current Dominant sp:..... & & Lestidae & 8 & & & & \\
\hline 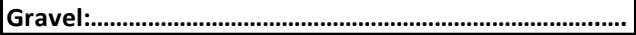 & & Libellulidae & 4 & & & & \\
\hline Sand::H & & Macroiidae & 3 & & & & \\
\hline Mud::How & & Platycnemidae & 10 & & & & \\
\hline 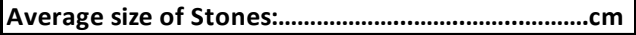 & & Protoneuridae & 8 & & & & \\
\hline Average size of Bedrock:....................................................... & Trichoptera & Calamoceratidae & 11 & & & & \\
\hline Hand Picking/Vissual Observation: & & Ecnomidae & 8 & & & & \\
\hline & & Dipseudopsidae & 10 & & & & \\
\hline & & Hydroptilidae & 6 & & & & \\
\hline Other Observations: & & Hydropsychidae $1 \mathrm{sp}$. & 4 & & & & \\
\hline & & Hydropsychidae $2 \mathrm{spp}$ & 6 & & & & \\
\hline & & Hydropsychidae $>2 \mathrm{sp}$ & 12 & & & & \\
\hline & & Lepidostomatidae & 10 & & & & \\
\hline & & Leptoceridae & 6 & & & & \\
\hline & & Philopotamidae & 10 & & & & \\
\hline & & Phryganeidae & 10 & & & & \\
\hline & & Polycentropodidae & 12 & & & & \\
\hline & & Psychomyiidae & 8 & & & & \\
\hline & & EDO(f) SCORE & & & & & \\
\hline & & NUMBER OF TAXA & & & & & \\
\hline & & ASPT & & & & & \\
\hline
\end{tabular}


Appendix 2: Modified EDOT Habitat Scores Criteria

\begin{tabular}{|c|c|c|c|}
\hline \multicolumn{2}{|c|}{ RIVER NAME: } & & LOCATION: \\
\hline \multicolumn{2}{|c|}{ STATION: } & & STREAM CLASS: \\
\hline \multicolumn{2}{|c|}{ LATITUDES: } & & RIVER BASIN: \\
\hline \multicolumn{2}{|c|}{ LONGITUDES: } & & DATE \& TIME: \\
\hline \multicolumn{2}{|c|}{ INVESTIGATOR(S): } & & PURPOSE FOR SURVEY: \\
\hline & \multirow{2}{*}{ Habitat Parameter } & \multicolumn{2}{|c|}{ Physical habitat condition or criteria } \\
\hline $\mathrm{S} / \mathrm{N}$. & & Optimal to Sub-ptimal & Marginal to Poor \\
\hline \multirow[t]{2}{*}{1} & Hydrological modification & $\begin{array}{l}\text { Little or absence of water abstraction for } \\
\text { irrigation and hydroelectic power project. }\end{array}$ & $\begin{array}{l}\text { Presence of water abstraction for irrigation, } \\
\text { water intake and supply, dams and } \\
\text { hydroeletric power project. }\end{array}$ \\
\hline & SCORE & $\begin{array}{|llllllllll|}20 & 19 & 18 & 17 & 16 & 15 & 14 & 13 & 12 & 11 \\
\end{array}$ & $\begin{array}{|llllllllll|}10 & 9 & 8 & 7 & 6 & 5 & 4 & 3 & 2 & 1 \\
\end{array}$ \\
\hline \multirow[t]{2}{*}{2} & Channel alteration & $\begin{array}{l}\text { Stream with normal pattern; Absent or present } \\
\text { of less than } 50 \% \text { channelization or dredging; } \\
\text { Evidence of past channelization i.e., dredging } \\
\text { may be present. Absence of sand, gravel and } \\
\text { mining extractions, animals trampling, and } \\
\text { construction of roads and bridges. }\end{array}$ & $\begin{array}{l}\text { Instream habitat greatly alterd or removed } \\
\text { entirely. Channelization might be extensive } \\
\text { with over } 50 \% \text { of stream reach channelized } \\
\text { and disrupted plus the evidence of sand, } \\
\text { gravel and mining extractions, animals } \\
\text { trampling, and construction of bridges. }\end{array}$ \\
\hline & SCORE & \begin{tabular}{|lllllllllll}
20 & 19 & 18 & 17 & 16 & 15 & 14 & 13 & 12 & 11 \\
\end{tabular} & $\begin{array}{|llllllllll|}10 & 9 & 8 & 7 & 6 & 5 & 4 & 3 & 2 & 1 \\
\end{array}$ \\
\hline \multirow[t]{2}{*}{3} & Channel sinuosity & $\begin{array}{l}\text { Presence of stream bends that increases the } \\
\text { length of a stream by } 2-4 \text { times longer if it was } \\
\text { in straight stream. }\end{array}$ & $\begin{array}{l}\text { Presence of stream bends that increases } \\
\text { the length of a stream to less than } 2 \text { times } \\
\text { longer if it was in straight stream. }\end{array}$ \\
\hline & SCORE & \begin{tabular}{|lllllllllll}
20 & 19 & 18 & 17 & 16 & 15 & 14 & 13 & 12 & 11 \\
\end{tabular} & $\begin{array}{|llllllllll|}10 & 9 & 8 & 7 & 6 & 5 & 4 & 3 & 2 & 1 \\
\end{array}$ \\
\hline \multirow[t]{2}{*}{4} & Channel flow status & $\begin{array}{l}\text { Water fill both lower banks and only }<25 \% \text { of } \\
\text { channel substrates is exposed. }\end{array}$ & $\begin{array}{l}\text { Very little water in the channel with }>25 \% \\
\text { of channel substrates is exposed. }\end{array}$ \\
\hline & SCORE & $\begin{array}{|llllllllll|}20 & 19 & 18 & 17 & 16 & 15 & 14 & 13 & 12 & 11 \\
\end{array}$ & $\begin{array}{|llllllllll|}10 & 9 & 8 & 7 & 6 & 5 & 4 & 3 & 2 & 1 \\
\end{array}$ \\
\hline \multirow[t]{2}{*}{5} & $\begin{array}{l}\text { Water quality and } \\
\text { appearances }\end{array}$ & $\begin{array}{l}\text { Relatively high water clarity, DO \& EC with } \\
\text { relatively low turbidity, water surface oils and } \\
\text { water odours. }\end{array}$ & $\begin{array}{l}\text { Relatively low water clarity, DO \& EC with } \\
\text { relatively high turbidity, water surface oils } \\
\text { and water odours. }\end{array}$ \\
\hline & SCORE & $\begin{array}{|llllllllll|}20 & 19 & 18 & 17 & 16 & 15 & 14 & 13 & 12 & 11 \\
\end{array}$ & $\begin{array}{|llllllllll|}10 & 9 & 8 & 7 & 6 & 5 & 4 & 3 & 2 & 1 \\
\end{array}$ \\
\hline \multirow[t]{2}{*}{6} & Direct domestic pollution & $\begin{array}{l}\text { Very little or absence of discaharge, disposal, } \\
\text { washing and bathing activities. }\end{array}$ & $\begin{array}{l}\text { Prensence of little, moderate and maximum } \\
\text { discaharge, disposal, washing and bathing } \\
\text { activities. }\end{array}$ \\
\hline & SCORE & \begin{tabular}{|llllllllll}
20 & 19 & 18 & 17 & 16 & 15 & 14 & 13 & 12 & 11 \\
\end{tabular} & $\begin{array}{|llllllllll|}10 & 9 & 8 & 7 & 6 & 5 & 4 & 3 & 2 & 1 \\
\end{array}$ \\
\hline \multirow[t]{2}{*}{7} & Direct industrial pollution & $\begin{array}{l}\text { Very little or absence of point sources and } \\
\text { diffused industrial discaharge and disposal. }\end{array}$ & $\begin{array}{l}\text { Prensence of moderate and maximum point } \\
\text { sources and diffused industrial discaharge } \\
\text { and disposal. }\end{array}$ \\
\hline & SCORE & $\begin{array}{|llllllllll|}20 & 19 & 18 & 17 & 16 & 15 & 14 & 13 & 12 & 11 \\
\end{array}$ & $\begin{array}{|lllllllll|}10 & 9 & 8 & 7 & 6 & 5 & 4 & 3 & 2 \\
\end{array}$ \\
\hline \multirow[t]{2}{*}{8} & Dumping of solid wastes & $\begin{array}{l}\text { Very minimal or absence of any evidence } \\
\text { regarding solid wastes dumping. }\end{array}$ & $\begin{array}{l}\text { Presence of clear evidence regarding solid } \\
\text { wastes dumping. }\end{array}$ \\
\hline & SCORE & $\begin{array}{|llllllllll|}20 & 19 & 18 & 17 & 16 & 15 & 14 & 13 & 12 & 11 \\
\end{array}$ & $\begin{array}{|lllllllll|}10 & 9 & 8 & 7 & 6 & 5 & 4 & 3 & 2 \\
\end{array}$ \\
\hline \multirow[t]{2}{*}{9} & Velocity/ depth regime & $\begin{array}{l}\text { Present of } 3 \text { to } 4 \text { velocity or depth regimes } \\
\text { (slow-shallow, fast-shallow, slow-deep of fast- } \\
\text { deep); slow is }<0.3 \mathrm{~m} / \mathrm{s} \text { and deep is }>0.5 \mathrm{~m} \text {. }\end{array}$ & \begin{tabular}{|l|} 
Present of $<3$ velocity or depth regimes; \\
usually with slow deep (if slow \& fast - \\
shallow regimes are absent, scores low). \\
\end{tabular} \\
\hline & SCORE & $\begin{array}{|llllllllll|}20 & 19 & 18 & 17 & 16 & 15 & 14 & 13 & 12 & 11 \\
\end{array}$ & $\begin{array}{|llllllllll|}10 & 9 & 8 & 7 & 6 & 5 & 4 & 3 & 2 & 1 \\
\end{array}$ \\
\hline \multirow[t]{2}{*}{10} & $\begin{array}{l}\text { Frequency of riffles (or } \\
\text { beds) }\end{array}$ & $\begin{array}{l}\text { Frequent riffles or beds occurances; distance } \\
\text { between riffles divide by width of the stream is } \\
\text { between } 1 \text { to } 15 \text {. }\end{array}$ & $\begin{array}{l}\text { Presence of shallow pools or occasionally } \\
\text { occured riffles or beds; distance between } \\
\text { riffles divide by stream width is }>15 \text {. }\end{array}$ \\
\hline & SCORE & $\begin{array}{|llllllllll|}20 & 19 & 18 & 17 & 16 & 15 & 14 & 13 & 12 & 11 \\
\end{array}$ & $\begin{array}{|lllllllll|}10 & 9 & 8 & 7 & 6 & 5 & 4 & 3 & 2 \\
\end{array}$ \\
\hline 11 & Embeddedness/siltation & $\begin{array}{l}\text { Gravel, cobbles and boulder particles are less } \\
\text { than } 50 \% \text { surrounded by fine sediments. }\end{array}$ & $\begin{array}{l}\text { Gravel, cobbles and boulder particles are } \\
>50 \% \text { surrounded by fine sediments. }\end{array}$ \\
\hline & SCORE & $\begin{array}{|llllllllll|}20 & 19 & 18 & 17 & 16 & 15 & 14 & 13 & 12 & 11 \\
\end{array}$ & $\begin{array}{|lllllllll|}10 & 9 & 8 & 7 & 6 & 5 & 4 & 3 & 2 \\
\end{array}$ \\
\hline
\end{tabular}




\begin{tabular}{|c|c|c|c|}
\hline 12 & Pool variability & $\begin{array}{l}\text { Presence of mix of large-shallow \& deep, and } \\
\text { small-shallow \& deep pools; majority of large- } \\
\text { deep pools and very few shallow pools. }\end{array}$ & Presence of small and shallow pools. \\
\hline & SCORE & $\begin{array}{|llllllllll|}20 & 19 & 18 & 17 & 16 & 15 & 14 & 13 & 12 & 11 \\
\end{array}$ & $\begin{array}{llllllll}10 & 9 & 8 & 7 & 6 & 5 & 4 & 3 \\
\end{array}$ \\
\hline \multirow[t]{2}{*}{13} & $\begin{array}{l}\text { Pool substrate } \\
\text { charactarization }\end{array}$ & $\begin{array}{l}\text { Presence of substrate materials, with mixture of } \\
\text { firm \& soft sand, gravel, mud, clay, root mats } \\
\text { and submerged vegetations. }\end{array}$ & $\begin{array}{l}\text { Presence of mud or clay or sand or bedrock } \\
\text { botom with no root mats or submerged } \\
\text { vegetations. }\end{array}$ \\
\hline & SCORE & $\begin{array}{llllllllll}20 & 19 & 18 & 17 & 16 & 15 & 14 & 13 & 12 & 11\end{array}$ & $\begin{array}{llllllllll}10 & 9 & 8 & 7 & 6 & 5 & 4 & 3 & 2 & 1\end{array}$ \\
\hline \multirow[t]{2}{*}{14} & Nurient enrichment & $\begin{array}{l}\text { Good levels of nutrients favourable organisms } \\
\text { survival. }\end{array}$ & $\begin{array}{l}\text { High or very low levels of nutrients } \\
\text { unavourable for organisms survival. }\end{array}$ \\
\hline & SCORE & $\begin{array}{|llllllllll|}20 & 19 & 18 & 17 & 16 & 15 & 14 & 13 & 12 & 11 \\
\end{array}$ & \begin{tabular}{lllllllll|}
10 & 9 & 8 & 7 & 6 & 5 & 4 & 3 & 2 \\
\end{tabular} \\
\hline \multirow[t]{3}{*}{15} & Informal settlements & $\begin{array}{l}\text { Absence of informal settlements and/or } \\
\text { industries or presence of very scartered }\end{array}$ & $\begin{array}{l}\text { Presence of some informal settlements and } \\
\text { industries. }\end{array}$ \\
\hline & SCORE: RIGHT BANK & 10 & 2 \\
\hline & SCORE: LEFT BANK & 10 & 3 \\
\hline \multirow[t]{3}{*}{16} & $\begin{array}{l}\text { Small and large scale } \\
\text { farming }\end{array}$ & $\begin{array}{l}\text { Very little or absence of small and/or large } \\
\text { scale agricultural activities. }\end{array}$ & $\begin{array}{l}\text { Presence of large and/or small scale } \\
\text { agricultural activities. }\end{array}$ \\
\hline & SCORE: RIGHT BANK & $\begin{array}{ll}8 & 7 \\
\end{array}$ & 2 \\
\hline & SCORE: LEFT BANK & 10 & 2 \\
\hline \multirow[t]{3}{*}{17} & Bank stability/erosion & $\begin{array}{l}\text { Presence of stable to moderate bank stability; } \\
\text { absent or presence of minimal evidence of } \\
\text { erosion or bank failure. }\end{array}$ & $\begin{array}{l}\text { Presence of moderately unstable to } \\
\text { unstable bank; >20\% of bank in reach has } \\
\text { eroded areas. }\end{array}$ \\
\hline & SCORE: RIGHT BANK & 10 & 2 \\
\hline & SCORE: LEFT BANK & 10 & 2 \\
\hline \multirow[t]{3}{*}{18} & $\begin{array}{l}\text { Riparian vegetations zone } \\
\text { width }\end{array}$ & $\begin{array}{l}\text { Presence of riparian zone with a width of more } \\
\text { than } 10 \text { meters; human activities have only } \\
\text { impacted riparian zone minimally. }\end{array}$ & $\begin{array}{l}\text { Presence of riparian zone with a width of } \\
\text { less than } 10 \text { meters; little or no riparian } \\
\text { vegetation due to impact associated with }\end{array}$ \\
\hline & SCORE: RIGHT BANK & $\begin{array}{lllll}10 & 9 & 8 & 7 & 6 \\
\end{array}$ & $\begin{array}{lllll}5 & 4 & 3 & 2 & 1 \\
\end{array}$ \\
\hline & SCORE: LEFT BANK & 10 & 2 \\
\hline \multirow[t]{3}{*}{19} & Bank vegetative protection & $\begin{array}{l}\text { More than } 70 \% \text { of the streambank surfaces are } \\
\text { protected by native vegetations. }\end{array}$ & $\begin{array}{l}\text { Less than } 70 \% \text { of the streambank surfaces } \\
\text { are protected by native vegetations. }\end{array}$ \\
\hline & SCORE: RIGHT BANK & 10 & 2 \\
\hline & SCORE: LEFT BANK & $\begin{array}{lllll}10 & 9 & 8 & 7 & 6 \\
\end{array}$ & $\begin{array}{llll}5 & 4 & 3 & 2 \\
\end{array}$ \\
\hline \multirow[t]{3}{*}{20} & Graze/ bank grass cover & More than $70 \%$ of the banks are covered by & Less than $70 \%$ of the banks are covered by \\
\hline & SCORE: RIGHT BANK & 10 & 2 \\
\hline & SCORE: LEFT BANK & 10 & 2 \\
\hline \multirow[t]{3}{*}{21} & $\begin{array}{l}\text { Presence of exotic } \\
\text { vegetation }\end{array}$ & $\begin{array}{l}\text { Absence of exotic vegetations or presence of } \\
\text { very few and little exotic vegetations. }\end{array}$ & $\begin{array}{l}\text { Presence of some or large number of exotic } \\
\text { vegetations. }\end{array}$ \\
\hline & SCORE: RIGHT BANK & 10 & 3 \\
\hline & SCORE: LEFT BANK & 10 & 2 \\
\hline \multirow[t]{2}{*}{22} & Canopy cover & $\begin{array}{l}\text { Presence of partially (50-75\%) to fully (75- } \\
100 \%) \text { shaded (overhead canopy cover) } \\
\text { throughout the sream reach. }\end{array}$ & $\begin{array}{l}\text { Presence of fully (0-25\%) to partially (25- } \\
50 \%) \text { exposed (overhead canopy cover) } \\
\text { throughout the sream reach. }\end{array}$ \\
\hline & SCORE & $\begin{array}{|llllllllll|}20 & 19 & 18 & 17 & 16 & 15 & 14 & 13 & 12 & 11 \\
\end{array}$ & $\begin{array}{|llllllllll|}10 & 9 & 8 & 7 & 6 & 5 & 4 & 3 & 2 & 1 \\
\end{array}$ \\
\hline \multirow[t]{2}{*}{23} & Epifaunal substrate & $\begin{array}{l}\text { More than } 50 \% \text { of substrate (mix of stable } \\
\text { habitat) favourable for epifauna colonization; } \\
\text { presence of new substrata (submerged logs } \\
\text { undercut banks, cobbles or other stable habitat) }\end{array}$ & $\begin{array}{l}\text { Less than } 50 \% \text { mix of stable habitat; lack of } \\
\text { habitat is obvious; lack or less than } \\
\text { desirable habitat; unstable substrate, } \\
\text { frequently disturbed, removed or lacking. }\end{array}$ \\
\hline & SCORE & $\begin{array}{|llllllllll|}20 & 19 & 18 & 17 & 16 & 15 & 14 & 13 & 12 & 11 \\
\end{array}$ & $\begin{array}{|lllllllll|}10 & 9 & 8 & 7 & 6 & 5 & 4 & 3 & 2 \\
\end{array}$ \\
\hline \multirow[t]{2}{*}{24} & Livestock keeping & $\begin{array}{l}\text { Absence or very little signs of livestock } \\
\text { trampling and droppings. }\end{array}$ & $\begin{array}{l}\text { Presence of livestock or signs of livestock } \\
\text { trampling and droppings. }\end{array}$ \\
\hline & SCORE & $\begin{array}{|llllllllll|}20 & 19 & 18 & 17 & 16 & 15 & 14 & 13 & 12 & 11 \\
\end{array}$ & $\begin{array}{|llllllllll|}10 & 9 & 8 & 7 & 6 & 5 & 4 & 3 & 2 & 1 \\
\end{array}$ \\
\hline 25 & Sediment deposition & $\begin{array}{l}\text { Pesence of little or slightly deposition of } \\
\text { sediments with }<30 \% \text { ( }<50 \% \text { of low gradient) of } \\
\text { the bottom affected by deposition. }\end{array}$ & $\begin{array}{l}\text { Pesence of moderate to severe sediments } \\
\text { deposition with }>30-50 \% \text { ( }>50 \% \text { of low } \\
\text { gradient) of the bottom affected by } \\
\text { deposition. }\end{array}$ \\
\hline & SCORE & $\begin{array}{|llllllllll|}20 & 19 & 18 & 17 & 16 & 15 & 14 & 13 & 12 & 11 \\
\end{array}$ & $\begin{array}{llllllll}9 & 8 & 7 & 6 & 5 & 4 & 3 & 2 \\
\end{array}$ \\
\hline
\end{tabular}




\section{Appendix 3.}

(a) List of sampling sites with their respective geomorphological and biotopes ( $\mathrm{S}=$ stone; $\mathrm{MV}=$ marginal vegetation; $\mathrm{GSM}=$ gravel-sand-mud) along Pangani basin.

\begin{tabular}{|c|c|c|c|c|c|c|c|c|c|c|c|}
\hline \multirow[b]{2}{*}{ Code } & \multicolumn{2}{|c|}{ SAMPLING STATIONS } & \multirow{2}{*}{$\begin{array}{c}\text { Habitat } \\
\text { Score }\end{array}$} & \multirow[b]{2}{*}{ Site category } & \multicolumn{2}{|c|}{ GPS Readings } & \multicolumn{3}{|c|}{ Biotopes } & \multicolumn{2}{|c|}{ Geomorphology } \\
\hline & River name & Site name & & & Latitude & Longitude & $S$ & MV & GSM & Landform & Ecoregion \\
\hline P1 & Themi & Olosha at AUWSA & 98 & Reference & 3.20311 & 36.43261 & $S$ & & & Mountains & $\mathrm{PH}$ \\
\hline P2 & Themi & Arusha-Moshi road & 94 & Reference & 3.21821 & 36.42147 & $S$ & & & Mountains & $\mathrm{PH}$ \\
\hline P3 & Themi & Lokii & 41 & Monitoring & 3.30349 & 36.46308 & $S$ & & GSM & Foot slopes & $\mathrm{PH}$ \\
\hline $\mathrm{P} 4$ & Themi & Sekei & 48 & Monitoring & 3.35101 & 36.70629 & $S$ & MV & GSM & Hills & $\mathrm{PH}$ \\
\hline P5 & Themi & Darajani polisi & 55 & Monitoring & 3.37299 & 36.69609 & $\mathrm{~S}$ & & & Plains & $\mathrm{PH}$ \\
\hline P6 & Themi & Daraja mbili & 58 & Monitoring & 3.38877 & 36.70003 & $S$ & & & Plains & $\mathrm{PH}$ \\
\hline P7 & Themi & Kijenge & 43 & Monitoring & 3.37909 & 36.69989 & $S$ & & & Plains & $\mathrm{PH}$ \\
\hline P8 & Malala & Nkoamaala & 99 & Reference & 3.19992 & 36.45367 & $\mathrm{~S}$ & & & Mountains & $\mathrm{PH}$ \\
\hline P9 & Nduruma & Deker Bruins & 59 & Monitoring & 3.24324 & 36.46941 & $S$ & & & Hills & $\mathrm{PH}$ \\
\hline $\mathrm{P} 10$ & Tengeru & Tengeru & 63 & Monitoring & 3.39491 & 36.82803 & $S$ & & GSM & Mountains & $\mathrm{PH}$ \\
\hline $\mathrm{P} 11$ & Ngarasero & NAIC & 92 & Reference & 3.35287 & 36.84014 & $S$ & & GSM & Hills & $\mathrm{PH}$ \\
\hline $\mathrm{P} 12$ & Themi & Naura & 78 & Monitoring & 3.37295 & 36.70106 & $\mathrm{~S}$ & & & Plains & $\mathrm{PH}$ \\
\hline P13 & Kikuletwa & Malala & 82 & Monitoring & 3.40123 & 36.77929 & $\mathrm{~S}$ & MV & GSM & Hills & PH \\
\hline P14 & Kikuletwa & Mbembe & 86 & Monitoring & 3.39508 & 36.82842 & $\mathrm{~S}$ & MV & GSM & Plains & $\mathrm{PH}$ \\
\hline P15 & Kikuletwa & Karangai & 40 & Monitoring & 3.26889 & 36.51506 & $\mathrm{~S}$ & MV & & Plains & PH \\
\hline P16 & USA river & Old Moshi-Arusha road & 62 & Monitoring & 3.22367 & 36.51787 & $\mathrm{~S}$ & & GSM & Hills & $\mathrm{PH}$ \\
\hline P17 & Maji ya chai & Darajani & 92 & Reference & 3.29883 & 36.89038 & $\mathrm{~S}$ & & & Hills & $\mathrm{PH}$ \\
\hline P18 & Maji ya chai & Mpakani & 92 & Reference & 3.31707 & 36.89245 & $S$ & & & Mountains & $\mathrm{PH}$ \\
\hline P19 & Tululusia & Campsite two & 93 & Reference & 3.23301 & 36.84428 & $S$ & & & Mountains & $\mathrm{PH}$ \\
\hline $\mathrm{P} 20$ & Ngarenanyuki & Campsite three & 91 & Reference & 3.24503 & 36.84304 & $S$ & & & Mountains & $\mathrm{PH}$ \\
\hline $\mathrm{P} 21$ & Maio & Maio & 93 & Reference & 3.24627 & 36.80967 & $S$ & & & Mountains & $\mathrm{PH}$ \\
\hline P22 & Mue & Mue bridge & 92 & Reference & 3.31033 & 37.48365 & & MV & GSM & Mountains & $\mathrm{PH}$ \\
\hline P23 & Magdarisho & Magdarisho & 95 & Reference & 3.35301 & 36.85289 & $S$ & MV & GSM & Hills & $\mathrm{PH}$ \\
\hline P24 & Kikafu & Moshi -Arusha road & 59 & Monitoring & 3.19119 & 37.13074 & $\mathrm{~S}$ & & GSM & Foot slopes & $\mathrm{PH}$ \\
\hline P25 & Kikafu & TPC & 42 & Monitoring & 3.43598 & 37.30309 & $\mathrm{~S}$ & MV & & Alluvial plains & $\mathrm{PH}$ \\
\hline P26 & Ona & Ona bridge & 97 & Reference & 3.31491 & 37.49507 & $\mathrm{~S}$ & & GSM & Mountains & $\mathrm{PH}$ \\
\hline $\mathrm{P} 27$ & Karanga & Kibo match & 56 & Monitoring & 3.20697 & 37.19028 & $S$ & & & Foot slopes & $\mathrm{PH}$ \\
\hline P28 & Rau & Msaranga & 54 & Monitoring & 3.20236 & 37.21379 & $S$ & & GSM & Foot slopes & $\mathrm{PH}$ \\
\hline P29 & Himo & Himo Bridge & 58 & Monitoring & 3.23454 & 37.32715 & $S$ & & GSM & Foot slopes & $\mathrm{PH}$ \\
\hline P30 & Ruvu & Kifaru bridge & 55 & Monitoring & 3.31732 & 37.33744 & $\mathrm{~S}$ & & GSM & Foot slopes & $\mathrm{PH}$ \\
\hline P31 & Pangani & Nyumba ya Mungu & 49 & Monitoring & 3.49859 & 37.28031 & & MV & & Alluvial plains & $\mathrm{PH}$ \\
\hline P32 & Pangani & Gunge, shimanjiro & 60 & Monitoring & 4.35198 & 37.52696 & $\mathrm{~S}$ & MV & GSM & Alluvial plains & $\mathrm{PH}$ \\
\hline P33 & Mkomazi & Mbuta & 44 & Monitoring & 4.39766 & 38.04593 & & MV & GSM & Alluvial plains & $\mathrm{PH}$ \\
\hline
\end{tabular}




\section{Continued}

\begin{tabular}{lcccccccccccc}
\hline P34 & Soni & Mombo & 57 & Monitoring & 4.53194 & 38.17307 & & MV & GSM & Alluvial plains & PH \\
P35 & Pangani & Maurui & 66 & Monitoring & 5.13615 & 38.38979 & MV & Foot slopes & PH \\
P36 & Luegera & Korongwe & 59 & Monitoring & 5.10091 & 38.27738 & MV & GSM & Alluvial plains & PH \\
P37 & Pangani & Hale Bridge & 51 & Monitoring & 5.17745 & 38.36138 & MV GSM & Plains & PC \\
P38 & Pangani & Mgombani & 42 & Monitoring & 5.20774 & 38.38741 & MV & Plains & PC \\
P39 & Pangani & Mwakinyumbi & 74 & Monitoring & 5.30141 & 38.59648 & MV & Alluvial plains & PC \\
P40 & Pangani & Nkhole & 70 & Monitoring & 5.51672 & 38.55349 & MV & GSM & Alluvial plains & PH \\
P41 & Pangani & Kwamkoro & 67 & Monitoring & 5.13284 & 38.61917 & S & MV & GSM & Mountains & PH \\
P42 & Pangani & Tundulu & 71 & Monitoring & 5.10342 & 38.64055 & S & MV & Mountains & PC \\
P43 & Pangani & Bulwa bridge & 91 & Reference & 5.09059 & 38.64201 & S & GSM & Mountains & PC \\
P44 & Pangani & Mkwajuni & 94 & Reference & 5.01101 & 38.78646 & S & GSM & Hills & PC \\
P45 & Pangani & Longuza & 92 & Reference & 5.05016 & 38.69997 & S & & Foot slopes & PC \\
P46 & Pangani & Sega & 74 & Monitoring & 5.05398 & 39.04626 & MV & Plains & PC \\
\hline
\end{tabular}

(b) List of sampling sites with their respective geomorphological and biotopes ( $\mathrm{S}=$ stone; $\mathrm{MV}=$ marginal vegetation; GSM = gravel-sand-mud) along Wami-Ruvu basin.

\begin{tabular}{|c|c|c|c|c|c|c|c|c|c|c|c|}
\hline \multirow[b]{2}{*}{ Code } & \multicolumn{2}{|c|}{ SAMPLING STATIONS } & \multirow{2}{*}{$\begin{array}{c}\text { Habitat } \\
\text { Score }\end{array}$} & \multirow[b]{2}{*}{ Site category } & \multicolumn{2}{|c|}{ GPS Readings } & \multicolumn{3}{|c|}{ Boitopes } & \multicolumn{2}{|c|}{ Geomorphology } \\
\hline & River name & Site name & & & Latitude & Longitude & $\mathrm{S}$ & MV & GSM & Landform & Ecoregion \\
\hline W01 & Wami & Dikurura & 91 & Reference & 6.11213 & 37.58025 & $\mathrm{~S}$ & & & Mountains & CEA \\
\hline W02 & Chazi & Magole & 69 & Monitoring & 6.10604 & 37.56956 & & MV & GSM & Foot slopes & CEA \\
\hline W03 & Wami & Mkindo & 66 & Monitoring & 6.23606 & 37.54913 & & MV & & Plains & CEA \\
\hline W04 & Wami & Matipwili & 91 & Reference & 6.24245 & 38.69144 & $\mathrm{~S}$ & MV & GSM & Plains & CCEA \\
\hline W05 & Wami & Dakawa & 88 & Monitoring & 6.26876 & 37.32009 & & MV & GSM & Plains & CEA \\
\hline W06 & Msowero & Msowero & 42 & Monitoring & 6.31891 & 37.12826 & & MV & GSM & Plains & CEA \\
\hline W07 & Wami & Tana & 96 & Reference & 6.47197 & 37.11995 & & MV & & Mountains & CEA \\
\hline W08 & Wami & Tami & 92 & Reference & 6.50112 & 37.12124 & & $\mathrm{MV}$ & & Mountains & CEA \\
\hline W09 & Kisangata & Mvumi & 64 & Monitoring & 6.58806 & 37.11997 & & MV & & Plains & CEA \\
\hline W10 & Wami & Mkondoa & 70 & Monitoring & 6.82929 & 36.98098 & & MV & GSM & Foot slopes & CEA \\
\hline W11 & Wami & Miyombo & 58 & Monitoring & 6.90895 & 36.97134 & & MV & GSM & Foot slopes & CEA \\
\hline R01 & Ngerengere & Dar-Morogoro bridge & 92 & Reference & 6.39082 & 38.02255 & & MV & GSM & Foot slopes & CEA \\
\hline R02 & Ruvu & Dar-Chalinze road bridge & 41 & Monitoring & 6.41431 & 38.41664 & & MV & GSM & Plains & CEA \\
\hline R03 & Morogoro & Morogoro water intake & 97 & Reference & 6.86157 & 37.00451 & $\mathrm{~S}$ & & & Mountains & CEA \\
\hline R04 & Mangwe & Chumbi & 95 & Reference & 6.94191 & 37.61718 & $\mathrm{~S}$ & & & Mountains & CEA \\
\hline R05 & Ngerengere & Tangeni & 93 & Reference & 6.94902 & 37.60588 & $\mathrm{~S}$ & & & Mountains & CEA \\
\hline R06 & Ngerengere & Konga & 77 & Monitoring & 6.90902 & 37.61153 & $\mathrm{~S}$ & & & Hill slopes & CEA \\
\hline R07 & Ngerengere & Mission & 79 & Monitoring & 6.89859 & 37.59915 & $\mathrm{~S}$ & & & Mountains & CEA \\
\hline R08 & Manga & Tawa & 96 & Reference & 7.01205 & 37.73188 & $\mathrm{~S}$ & & & Plains & CEA \\
\hline
\end{tabular}




\section{Continued}

\begin{tabular}{|c|c|c|c|c|c|c|c|c|c|c|c|}
\hline R09 & Ruvu & Kibungo & 94 & Reference & 7.02812 & 37.81102 & S & & & Plains & CEA \\
\hline $\mathrm{R} 10$ & Ruvu & Mzinga & 74 & Monitoring & 7.05103 & 37.52424 & & MV & GSM & Hill slopes & CEA \\
\hline R11 & Mgeta & Kibaoni & 63 & Monitoring & 7.03538 & 37.56901 & & MV & GSM & Plains & CEA \\
\hline $\mathrm{R} 12$ & Mzinga & Mzinga bridge & 58 & Monitoring & 6.88901 & 37.61199 & & MV & GSM & Plains & CEA \\
\hline $\mathrm{R} 13$ & Mzinga & Luhungo & 92 & Reference & 6.90482 & 37.63701 & S & MV & GSM & Plains & CEA \\
\hline R14 & Morogoro & Morogoro industrial area & 41 & Monitoring & 6.76961 & 37.67264 & & & GSM & Plains & CEA \\
\hline $\mathrm{R} 15$ & Morogoro & Morogoro bridge & 52 & Monitoring & 6.84557 & 37.67232 & & MV & GSM & Plains & CEA \\
\hline R16 & Ruvu & Kinole intake & 97 & Reference & 6.92495 & 37.76934 & S & & & Mountains & CEA \\
\hline $\mathrm{R} 17$ & Ruvu & Mji mpya @ Kikundi & 58 & Monitoring & 6.82301 & 37.66792 & & & GSM & Plains & CEA \\
\hline R18 & Mgeta & @ Mgeta & 42 & Monitoring & 7.03333 & 37.56673 & S & MV & GSM & Foot slopes & CEA \\
\hline R19 & Mgeta & Duthumi & 94 & Reference & 7.41171 & 37.77663 & $S$ & & & Mountains & CEA \\
\hline R20 & Mvuha & Tulo primary school & 92 & Reference & 7.24034 & 37.91775 & $S$ & MV & & Hill slopes & CEA \\
\hline $\mathrm{R} 21$ & Mzumbe & Mlali & 84 & Monitoring & 6.90127 & 37.56162 & & & GSM & Foot slopes & CEA \\
\hline R22 & Ngerengere & Kingolwira & 44 & Monitoring & 6.75184 & 37.75761 & $S$ & & GSM & Foot slopes & CEA \\
\hline $\mathrm{R} 23$ & Ngerengere & Mgude & 47 & Monitoring & 6.76376 & 38.14456 & & MV & GSM & Foot slopes & CEA \\
\hline $\mathrm{R} 24$ & Ngerengere & Bwawani & 86 & Monitoring & 6.65139 & 38.03811 & & & GSM & Foot slopes & CEA \\
\hline R25 & Ruvu & Mindu & 50 & Monitoring & 6.85548 & 37.61399 & & MV & GSM & Plains & CEA \\
\hline R26 & Ruvu & Kidunda & 76 & Monitoring & 7.26963 & 38.21723 & & MV & GSM & Mountains & CEA \\
\hline R27 & Ruvu & Kongo & 82 & Monitoring & 6.53912 & 38.83 & & MV & GSM & Mountains & CEA \\
\hline R28 & Ruvu & Ruvu near estuary & 53 & Monitoring & 6.39714 & 38.8698 & & MV & GSM & Hill slopes & CCEA \\
\hline
\end{tabular}

Appendix 4: Macroinvertebrate Species Collected Based on Major Site Categories

\begin{tabular}{cccccccccccc}
\hline & \multicolumn{3}{c}{ PANGANI SITES } & \multicolumn{3}{c}{ WAMI-RUVU SITES } & \multicolumn{2}{c}{ TOTAL } \\
\cline { 2 - 10 } TAXA & \multicolumn{2}{c}{ REFERENCE } & \multicolumn{2}{c}{ MONITORING } & REFERENCE & MONITORING & ALL SITES \\
\cline { 2 - 10 } & Abundance & $\%$ & Abundance & $\%$ & Abundance & $\%$ & Abundance & $\%$ & Abundance & $\%$ \\
\hline Hirudinidae & 0 & 0.0 & 8 & 0.15 & 0 & 0.0 & 6 & 0.17 & 14 & 0.11 \\
Glossiphoniidae & 0 & 0.0 & 14 & 0.27 & 0 & 0.0 & 5 & 0.14 & 19 & 0.15 \\
Naididae/Tubificidae & 0 & 0.0 & 50 & 0.96 & 0 & 0.0 & 9 & 0.25 & 59 & 0.47 \\
Dytiscidae & 31 & 1.26 & 82 & 1.57 & 17 & 1.23 & 99 & 2.41 & $229^{* *}$ & 1.81 \\
Dryopidae/Elmidae & 9 & 0.36 & 115 & 2.20 & 12 & 0.87 & 96 & 2.71 & $232^{* *}$ & 1.84 \\
Gyrinidae & 64 & 2.59 & 50 & 0.96 & 0 & 0.0 & 47 & 1.33 & $161^{*}$ & 1.27 \\
Haliplidae & 2 & 0.08 & 30 & 0.57 & 0 & 0.0 & 52 & 1.47 & 84 & 0.67 \\
Hydraenidae & 11 & 0.45 & 28 & 0.54 & 0 & 0.0 & 30 & 0.85 & 69 & 0.55 \\
Hydrophilidae & 30 & 1.2 & 43 & 0.82 & 0 & 0.0 & 58 & 1.64 & $131^{*}$ & 1.04 \\
Limnichidae & 12 & 0.49 & 22 & 0.42 & 0 & 0.0 & 0 & 0.0 & 34 & 0.27 \\
Psephenidae & 28 & 1.13 & 55 & 1.05 & 26 & 1.88 & 45 & 1.27 & $154^{*}$ & 1.22 \\
Scirtidae & 5 & 0.20 & 34 & 0.65 & 0 & 0.0 & 22 & 0.62 & 61 & 0.48 \\
\hline
\end{tabular}




\section{Continued}

\begin{tabular}{|c|c|c|c|c|c|c|c|c|c|c|}
\hline Amphipoda & 0 & 0.0 & 5 & 0.10 & 2 & 0.14 & 22 & 0.62 & 29 & 0.23 \\
\hline Atyidae & 0 & 0.0 & 17 & 0.33 & 0 & 0.0 & 16 & 0.45 & 33 & 0.26 \\
\hline Palaemonidae & 0 & 0.0 & 15 & 0.29 & 2 & 0.14 & 29 & 0.82 & 46 & 0.36 \\
\hline Potamonautidae & 59 & 2.39 & 209 & 4.00 & 19 & 1.37 & 45 & 1.27 & $332^{\star *}$ & 2.63 \\
\hline Athericidae & 55 & 2.23 & 132 & 2.53 & 31 & 2.24 & 22 & 0.62 & $240^{* *}$ & 1.90 \\
\hline Ceratopogonidae & 14 & 0.57 & 183 & 3.50 & 0 & 0.0 & 43 & 1.21 & $240^{\star *}$ & 1.90 \\
\hline Chironomidae & 68 & 2.75 & 1455 & 27.84 & 45 & 3.25 & 639 & 18.02 & $2207^{\star * *}$ & 17.48 \\
\hline Culicidae & 0 & 0.0 & 57 & 1.09 & 0 & 0.0 & 52 & 1.47 & $109^{*}$ & 0.86 \\
\hline Dixidae & 62 & 2.51 & 31 & 0.59 & 7 & 0.51 & 45 & 1.27 & $145^{*}$ & 1.15 \\
\hline Ephydridae & 3 & 0.12 & 14 & 0.27 & 0 & 0.0 & 5 & 0.14 & 22 & 0.17 \\
\hline Muscidae & 0 & 0.0 & 31 & 0.59 & 0 & 0.0 & 11 & 0.31 & 42 & 0.33 \\
\hline Simuliidae & 17 & 0.69 & 384 & 7.35 & 0 & 0.0 & 137 & 3.86 & $538^{* *}$ & 4.26 \\
\hline Tabanidae & 34 & 1.38 & 84 & 1.61 & 17 & 1.23 & 50 & 1.41 & $185^{*}$ & 1.46 \\
\hline Tipulidae & 38 & 1.54 & 51 & 0.98 & 22 & 1.59 & 59 & 1.66 & $170^{*}$ & 1.35 \\
\hline Baetidae & 751 & 30.40 & 470 & 8.99 & 235 & 16.96 & 227 & 6.40 & $1683^{* * *}$ & 13.33 \\
\hline Caenidae & 115 & 4.66 & 266 & 5.09 & 26 & 1.88 & 128 & 3.61 & $535^{\star *}$ & 4.24 \\
\hline Dicercormyzidae & 19 & 0.77 & 28 & 0.54 & 36 & 2.60 & 30 & 0.85 & $113^{*}$ & 0.89 \\
\hline Ephemerythidae & 8 & 0.32 & 15 & 0.29 & 22 & 0.62 & 52 & 1.47 & 97 & 0.77 \\
\hline Heptageniidae & 41 & 1.66 & 45 & 0.86 & 29 & 2.09 & 79 & 2.23 & $194^{*}$ & 1.54 \\
\hline Leptophlebiidae & 29 & 1.17 & 64 & 1.22 & 34 & 2.45 & 66 & 1.86 & $193^{*}$ & 1.53 \\
\hline Oligoneuridae & 62 & 2.51 & 18 & 0.34 & 82 & 5.92 & 12 & 0.34 & $174^{*}$ & 1.38 \\
\hline Polymitarcyidae & 38 & 1.54 & 6 & 0.11 & 26 & 1.88 & 0 & 0.0 & 70 & 0.55 \\
\hline Prosopistomatidae & 57 & 2.31 & 16 & 0.31 & 45 & 3.25 & 41 & 1.16 & $159^{*}$ & 1.26 \\
\hline Tricorythidae & 10 & 0.40 & 5 & 0.10 & 23 & 1.66 & 32 & 0.90 & 70 & 0.55 \\
\hline Lymnaeidae & 0 & 0.0 & 12 & 0.23 & 0 & 0.0 & 25 & 0.71 & 37 & 0.29 \\
\hline Physidae & 0 & 0.0 & 22 & 0.42 & 0 & 0.0 & 19 & 0.54 & 41 & 0.32 \\
\hline Planorbidae & 0 & 0.0 & 11 & 0.21 & 0 & 0.0 & 18 & 0.51 & 29 & 0.23 \\
\hline Thiaridae & 0 & 0.0 & 9 & 0.17 & 0 & 0.0 & 28 & 0.79 & 37 & 0.29 \\
\hline Belastomatidae & 17 & 0.69 & 0 & 0.0 & 24 & 1.73 & 8 & 0.23 & 49 & 0.39 \\
\hline Corixidae & 6 & 0.24 & 152 & 2.39 & 10 & 0.72 & 0 & 0.0 & $168^{*}$ & 1.33 \\
\hline Gerridae & 9 & 0.36 & 43 & 0.82 & 0 & 0.0 & 19 & 0.54 & 71 & 0.56 \\
\hline Hydrometridae & 6 & 0.24 & 14 & 0.27 & 0 & 0.0 & 10 & 0.28 & 30 & 0.24 \\
\hline Naucoridae & 14 & 0.57 & 65 & 1.24 & 22 & 1.59 & 90 & 2.54 & $191^{*}$ & 1.51 \\
\hline Nepidae & 9 & 0.36 & 13 & 0.25 & 0 & 0.0 & 0 & 0.0 & 22 & 0.17 \\
\hline Notonectidae & 13 & 0.53 & 113 & 2.16 & 0 & 0.0 & 0 & 0.0 & $126^{*}$ & 1.0 \\
\hline Pleidae & 5 & 0.20 & 5 & 0.10 & 0 & 0.0 & 4 & 0.11 & 14 & 0.11 \\
\hline Veliidae & 20 & 0.81 & 64 & 1.22 & 12 & 0.87 & 71 & 2.00 & $167^{\star}$ & 1.32 \\
\hline
\end{tabular}




\section{Continued}

\begin{tabular}{|c|c|c|c|c|c|c|c|c|c|c|}
\hline Hydridae & 0 & 0.0 & 4 & 0.08 & 0 & 0.0 & 8 & 0.23 & 12 & 0.10 \\
\hline Pyralidae & 5 & 0.20 & 1 & 0.02 & 2 & 0.14 & 3 & 0.08 & 11 & 0.09 \\
\hline Aeshnidae & 43 & 1.74 & 102 & 1.95 & 33 & 2.38 & 80 & 2.26 & $258^{\star *}$ & 2.04 \\
\hline Calopterygidae & 57 & 2.31 & 31 & 0.59 & 37 & 2.67 & 83 & 2.34 & $208^{\star *}$ & 1.65 \\
\hline Chlorocyphidae & 28 & 1.13 & 13 & 0.25 & 22 & 1.59 & 71 & 2.00 & $134^{*}$ & 1.06 \\
\hline Chlorolestidae & 0 & 0.0 & 7 & 0.13 & 6 & 0.43 & 11 & 0.31 & 24 & 0.19 \\
\hline Coenagrionidae & 32 & 1.30 & 92 & 1.76 & 20 & 1.44 & 86 & 2.43 & $230^{* *}$ & 1.82 \\
\hline Corduliidae & 5 & 0.20 & 38 & 0.73 & 13 & 0.94 & 56 & 1.58 & $112^{*}$ & 0.89 \\
\hline Gomphidae & 33 & 1.34 & 68 & 1.30 & 12 & 0.87 & 42 & 1.18 & $155^{*}$ & 1.23 \\
\hline Lestidae & 0 & 0.0 & 12 & 0.23 & 15 & 1.08 & 47 & 1.33 & 74 & 0.59 \\
\hline Libellulidae & 0 & 0.0 & 28 & 0.54 & 29 & 2.09 & 52 & 1.47 & $109^{*}$ & 0.86 \\
\hline Macromiidae & 0 & 0.0 & 18 & 0.34 & 0 & 0.0 & 8 & 0.23 & 26 & 0.21 \\
\hline Perlidae & 19 & 0.77 & 0 & 0.0 & 27 & 1.95 & 13 & 0.37 & 59 & 0.47 \\
\hline Turbellaria & 0 & 0.0 & 13 & 0.25 & 0 & 0.0 & 14 & 0.39 & 27 & 0.21 \\
\hline Corbiculidae & 0 & 0.0 & 3 & 0.04 & 0 & 0.0 & 1 & 0.03 & 4 & 0.03 \\
\hline Sphaeriidae & 0 & 0.0 & 4 & 0.08 & 0 & 0.0 & 1 & 0.03 & 5 & 0.04 \\
\hline Unionidae & 0 & 0.0 & 1 & 0.02 & 0 & 0.0 & 1 & 0.03 & 2 & 0.02 \\
\hline Corydalidae & 4 & 0.16 & 2 & 0.04 & 0 & 0.0 & 6 & 0.17 & 12 & 0.10 \\
\hline Sialidae & 3 & 0.12 & 1 & 0.02 & 6 & 0.43 & 3 & 0.08 & 13 & 0.10 \\
\hline Calamoceratidae & 112 & 4.53 & 5 & 0.01 & 58 & 4.18 & 38 & 1.07 & $213^{\star *}$ & 1.74 \\
\hline Dipseudopsidae & 16 & 0.65 & 4 & 0.08 & 34 & 2.45 & 32 & 0.90 & 86 & 0.68 \\
\hline Ecnomidae & 21 & 0.85 & 11 & 0.21 & 6 & 0.43 & 32 & 0.90 & 70 & 0.55 \\
\hline Hydroptilidae & 13 & 0.53 & 9 & 0.17 & 3 & 0.22 & 23 & 0.65 & 48 & 0.38 \\
\hline Hydropsychidae & 55 & 0.22 & 32 & 0.61 & 56 & 0.40 & 31 & 0.87 & $174^{*}$ & 1.38 \\
\hline Lepidostomatidae & 20 & 0.81 & 0 & 0.0 & 40 & 2.89 & 35 & 0.99 & 95 & 0.75 \\
\hline Leptoceridae & 59 & 2.39 & 19 & 0.36 & 6 & 0.43 & 27 & 0.76 & $111^{*}$ & 0.88 \\
\hline Philopotamidae & 69 & 2.79 & 19 & 0.36 & 52 & 3.75 & 32 & 0.90 & $172^{*}$ & 1.36 \\
\hline Phryganeidae & 25 & 1.01 & 4 & 0.08 & 20 & 1.44 & 45 & 1.27 & 94 & 0.74 \\
\hline Polycentropodidae & 58 & 2.35 & 4 & 0.08 & 54 & 3.90 & 34 & 0.96 & $150^{*}$ & 1.19 \\
\hline Psychomyiidae & 22 & 0.89 & 27 & 0.52 & 9 & 0.65 & 28 & 0.79 & 86 & 0.68 \\
\hline TOTAL & 2470 & & 5227 & & 1386 & & 3546 & & 12629 & 100.0 \\
\hline
\end{tabular}

